\title{
NATO's strategic narratives: Angelina Jolie and the alliance's celebrity and visual turn
}

\author{
Katharine A. M. Wright ${ }^{1 \star}$ (D) and Annika Bergman Rosamond ${ }^{2}$ \\ ${ }^{1}$ School of Geography, Politics and Sociology, Newcastle University, Newcastle, United Kingdom and ${ }^{2}$ Department of \\ Political Science, Lund University, Sweden \\ *Corresponding author. Email: Katharine.a.m.wright@newcastle.ac.uk
}

(Received 11 June 2020; revised 23 March 2021; accepted 24 March 2021; first published online 10 May 2021)

\begin{abstract}
Angelina Jolie's high-profile visit to NATO in 2018 signals a move to brand the alliance's strategic narrative within the language of celebrity through engagement with popular culture. The partnership represents a significant change in the alliance's approach to global security. It also builds on a shift in NATO's self-narrative through the advocacy of gender justice related to the Women, Peace and Security (WPS) agenda. Rather than fading into the background, NATO appears to be pursuing the limelight for the purpose of 'awareness raising' as a tool to implement the WPS agenda. Drawing upon feminist scholarship on the WPS agenda, NATO, and research on celebrity humanitarianism and politics, we provide a critical study of this change in NATO's strategic narrative, through the analysis of visual and textual material related to Jolie's visit to NATO. Our focus is on the significance of this partnership and its contribution to legitimising the alliance's self-defined 'military leadership' in the area of conflict-related sexual violence. While Jolie's visit to NATO opened the alliance to public scrutiny it also symbolised a form of militarism, surrounded by orchestrated visual representations. As such, it only marginally disrupted the militarist logic present in NATO's wider WPS engagement.
\end{abstract}

Keywords: NATO; Angelina Jolie; Celebrity; Strategic Narratives; Conflict-Related Sexual- and Gender-Based Violence; Women; Peace and Security; Popular Culture

\section{Introduction}

On 31 January 2018 the North Atlantic Treaty Organisation (NATO) hosted its first joint press conference with an internationally recognised celebrity. Angelina Jolie's visit to the NATO Headquarters in Brussels was preceded by the publication of a jointly authored op-ed published in The Guardian. Her appearance at NATO was visually projected in social media using the hashtag '\#weareNATO' and featured in celebrity news magazines including PopSugar and People, a change from the usual press outlets and audience engaged with the political-military alliance. NATO released 74 photographs of her visit, including 'behind-the-scenes' shots ${ }^{1}$. Angelina Jolie is no stranger to such political engagement, having participated in various government-led initiatives to eradicate sexual violence in conflict. ${ }^{2}$ Given Angelina Jolie's celebrity and

\footnotetext{
${ }^{\dagger}$ The online version of this article has been updated since original publication. A notice detailing the changes has also been published at https://doi.org/10.1017/S0260210521000310.

${ }^{1}$ NATO, 'Visit to NATO by the Special Envoy for the United Nations High Commissioner for Refugees' (2018), available at: $\{$ https://www.nato.int/cps/en/natohq/photos_151258.htm\} accessed 11 April 2018.

${ }^{2}$ Annika Bergman Rosamond, 'The digital politics of celebrity activism against sexual violence: Angelina Jolie as global mother', in Laura J. Shepherd and Cait Hamilton (eds), Understanding Popular Culture and World Politics in the Digital

(C) The Author(s), 2021. Published by Cambridge University Press on behalf of the British International Studies Association. This is an Open Access article, distributed under the terms of the Creative Commons Attribution-NonCommercial-NoDerivatives licence (http://creativecommons.org/licenses/by-nc-nd/4.0/), which permits non-commercial re-use, distribution, and reproduction in any medium, provided the original work is unaltered and is properly cited. The written permission of Cambridge University Press must be obtained for commercial re-use or in order to create a derivative work.
} 
humanitarian presence and recognition on the global stage, and within the global entertainment industry, it is perhaps not surprising that footage and commentary were made available to sizeable worldwide audiences. However, and as we shall discuss further below, such celebrity footage tends to be more attentive to the beauty, dignity, and dress sense of the celebrity in question, rather than the substance of the political and ethical message that the individual seeks to highlight; ${ }^{3}$ in this case NATO's role in responding to conflict-related sexual- and gender-based violence (CRSGBV).

For NATO, this short-lived partnership with Jolie was significant for two reasons. First, it marked the alliance's most public engagement with the issue of CRSGBV to date. NATO's prior engagement with the Women, Peace and Security (WPS) agenda had to some extent sidelined CRSGBV. ${ }^{4}$ Second, despite the proliferation of celebrity endorsement and partnerships with international organisations, most notably the United Nations and its agencies, ${ }^{5}$ this was NATO's first engagement with a global celebrity. It therefore represented a significant change in the projection of NATO's self-narrative, visually and textually, particularly for an organisation whose public diplomacy was described by its own Secretary General in 2007 as being in the Stone Age' ${ }^{6}$ As we argue in this article, pairing up with Jolie appeared to be an attempt to engage a public with little, or no knowledge of NATO, but, who nonetheless are interested in Jolie's engagements with global politics. It could also challenge the 'banal militarism' that has defined NATO and left it largely untouched by meaningful public scrutiny. ${ }^{7}$ However, rather than opening NATO to further scrutiny, we argue that the celebrity visit and its digital transmission in popular culture symbolised a different form of mediatised militarism, sustained by orchestrated visual representations made possible through new digital information and communication technologies. ${ }^{8}$

Jolie's engagement with NATO's CRSGBV agenda is in line with her long-standing commitment to the eradication of CRSGBV globally. Jolie has extensive experience working with multiple institutions, ${ }^{9}$ across humanitarian projects ${ }^{10}$ and with politicians ${ }^{11}$ bringing attention to such things as the global refugee crisis and gendered violence. ${ }^{12}$ Though our piece is broadly located within research on celebrity activism, our main focus in this article is on the significance of Jolie's partnership with NATO rather than the distinctiveness of Jolie's humanitarianism or her reasons for promoting NATO as a global gender actor. Indeed, Jolie herself admitted on the occasion of her visit to NATO that her knowledge of NATO is limited: 'I've been learning about NATO, where they've been doing some very good work and where they can improve and change.' ${ }^{\text {' }}$

Age (Oxford: Routledge, 2016); Sara E. Davies and Jacqui True, 'Norm entrepreneurship in foreign policy: William Hague and the prevention of sexual violence in conflict', Foreign Policy Analysis, 13 (2017), pp. 701-21.

${ }^{3}$ Bergman Rosamond, 'The digital politics of celebrity activism'.

${ }^{4}$ Katharine A. M. Wright, Matthew Hurley, and Jesus Gil Ignacio Ruiz, NATO, Gender and the Military: Women Organising From Within (London: Routledge, 2019), p. 121.

${ }^{5}$ Annika Bergman Rosamond, 'Global motherhood and celebrity politics in the 21st century', in Lucy B. Hall Anna L. Weissman, and Laura J. Shepherd (eds), Troubling Motherhood (Oxford: Oxford University Press, 2020); Andrew F. Cooper, Celebrity Diplomacy (London: Paradigm, 2008); Andrew F. Cooper, 'UN celebrity-driven public diplomacy', in Nancy Snow and Philip M. Taylor (eds), Routledge Handbook of Public Diplomacy ( $2^{\text {nd }}$ edn, New York: Routledge, 2020), pp. 187-94.

${ }^{6}$ Jaap de Hoop Scheffer, 'Speech by NATO Secretary General, Jaap de Hoop Scheffer at the Seminar on "Public Diplomacy in NATO-led Operations”, NATO (2007), available at: \{http://www.nato.int/ docu/speech/2007/s071008a.html\} accessed 20 July 2015.

${ }^{7}$ Merje Kuus "'Love, peace and Nato": Imperial subject-making in Central Europe', Antipode, 39:2 (2007), p. 269.

${ }^{8}$ Susan T. Jackson, Rhys Crilley, Ilan Manor, Catherine Baker, Modupe Oshikoya, Jutta Joachim, Nick Robinson, Andrea Schneiker, Nicole Sunday Grove, and Cynthia Enloe, 'Forum: Militarization 2.0: Communication and the normalization of political violence in the digital age', International Studies Review (2020), pp. 1-26.

${ }^{9}$ Bergman Rosamond, 'Global motherhood and celebrity politics'.

${ }^{10}$ Annika Bergman Rosamond and Catia Gregoratti, 'Neoliberal turns in global humanitarian governance: Corporations, celebrities and the construction of the entrepreneurial refugee woman', Journal of Humanitarian Affairs (2021).

${ }^{11}$ Davies and True, 'Norm entrepreneurship in foreign policy'.

${ }^{12}$ Bergman Rosamond, 'Global motherhood and celebrity politics'.

${ }^{13}$ NATO, 'Joint Press Conference by NATO Secretary General Jens Stoltenberg with Special Envoy for the United Nations High Commissioner for Refugees Angelina Jolie’ (2018), available at: \{https://www.nato.int/cps/ua/natohq/opinions_151264. htm?selectedLocale=en\} accessed 11 April 2018. 
Yet, our contention is that her partnership, albeit brief and not grounded in profound a priori knowledge of the alliance, can tell us something about NATO's self-narrative and the stories that NATO seeks to tell about the WPS agenda through a combination of orthodox channels and digital popular culture. We propose that NATO's association with a globally recognised celebrity such as Angelina Jolie has the potential to transform NATO's identity narrative by adding public recognition and glamour to its projected self. Indeed, the study of celebrities, as security actors, offers particular insights, precisely because they are highly visible, and, as such can appeal to otherwise apolitical and perhaps disengaged mass audiences. ${ }^{14}$ Specifically, while the reception of such narratives is often overlooked $^{15}$ in focusing on NATO's projected self-narrative and its reception in media coverage, we demonstrate how visual representations become integral to shaping the strategic narrative itself and its wider reception. This article therefore makes an important contribution to understanding the reception of strategic narratives and the importance of interrogating visuals. In so doing, we argue that paying attention to popular culture, which celebrity and star power can be constitutive of, is key to understanding the reception of both identity and issue focused strategic narratives given celebrities' questioning of 'any sharp distinction between elite and popular geopolitical discourses. ${ }^{16}$ In taking a critical feminist approach we deepen this contribution by demonstrating how the successful reception of such narratives in popular culture is inherently gendered.

To this end we explore NATO's use of strategic narratives, specifically its identity narrative or what could be defined as its self-narrative, which in turn shapes the issue narrative of CRSGBV. Given the emphasis on the importance of 'seeing' such narratives ${ }^{17}$ we draw on both textual and visual representations in our analysis, largely communicated through digital channels, the latter being all the more important when a celebrity is involved in the narrative projection. Our analysis therefore concerns key texts and images released by NATO and Angelina Jolie, along with media and social media coverage. This allows us to determine how the visit was received and projected through (social) media, and specifically the value of the partnership for shaping NATO's selfnarrative and the distinct issue narrative of CRSGBV.

We commence our article by introducing our method and material drawing upon scholarship on strategic narratives and visual security studies. In so doing we consider what a critical feminist reading of NATO's self-narrative can add to our understanding of the alliance itself and what it can tell us about the role of celebrity in global politics. We then discuss celebrity as a concept and identify the key premises of celebrity interventions at the global level. Next we locate our contribution within the burgeoning feminist literature on the WPS agenda, and the place of CRSGBV within it, specifically we focus on how the issue narrative has developed over time. This sets the stage for our feminist analysis of NATO's self-narrative and the place of WPS within it, reflecting on how Jolie's gendered personas, advocacy, and track record as a humanitarian framed the fleeting NATO-Jolie partnership and fed into NATO's attempt to frame itself as a 'global military leader' in addressing CRSGBV, through the projection and reception of the visit in popular culture and celebrity.

\section{Strategic narratives: Visual and textual reception}

Narratives about celebrities are told visually and textually across texts, ${ }^{18}$ often through digital channels. For example, Angelina Jolie's conduct of celebrity activism employs language pertaining

\footnotetext{
${ }^{14}$ Bergman Rosamond, 'The digital politics of celebrity activism'; Bergman Rosamond, 'Global motherhood and celebrity politics'.

${ }^{15}$ Rhys Crilley, 'Seeing strategic narratives?', Critical Studies on Security, 3:3 (2015), pp. 331-3; Louise Pears, 'Ask the audience: Television, security and homeland', Critical Studies on Terrorism, 9:1 (2016), pp. 76-96.

${ }^{16}$ Matthew C. Benwell, Klaus Dodds, and Alasdair Pinkerton, 'Celebrity geopolitics', Political Geography, $31: 7$ (2012), p. 405.

${ }^{17}$ Alister Miskimmon, Ben O’Loughlin, and Laura Roselle, Strategic Narratives: Communication Power and the New World Order (Abingdon: Routledge, 2013); Crilley, 'Seeing strategic narratives?'; Pears, 'Ask the audience'.

${ }^{18}$ Gillian Rose, 'On the relation between "visual research methods” and contemporary visual culture', Sociological Review, 62:1 (2014), pp. 24-46.
} 
to her aesthetically pleasing looks and choice of outfits, and increasingly, those attributes are digitally represented across a variety of texts and visuals. ${ }^{19}$ This adds to Jolie's presence and recognition in global politics. Thus, it is necessary to consider what texts and images actually do and enable through their circulation'. ${ }^{20}$ This is often a gendered process whereby celebrities of both genders are assigned stereotypical qualities. For example, texts and visuals telling the story of Sean Penn represent him within Western notions of masculine protection of distant vulnerable others. ${ }^{21}$ Feminist literature on visual security has focused on the visual portrayal of Afghan women as vulnerable others in need of Western protection, which in turn enabled what became a NATO-led intervention. ${ }^{22}$ Much of the visual security literature has been concerned with how images construct the referent object of security. For example, Lene Hansen's argument is that images can 'constitute something or someone as threatened and in need of immediate defence'. ${ }^{23}$ However, our focus here is on how texts but also visuals are integral to the legitimisation of the projected strategic selfnarrative of NATO as a 'military leader' on $\mathrm{CRSGBV}^{24}$ and in turn the shaping of CRSGBV as an issue narrative through Jolie's visit and their reception in traditional and social media coverage.

The strategic use of narratives enables NATO to settle its preferences and create a story about the self 'to construct a shared meaning of the past, present and future of international politics to shape the behaviour of domestic and international actors' ${ }^{25}$ A narrative that has gained widespread acceptance can, moreover, determine what is imaginable or indeed actionable and render an actor 'legitimate and capable'. ${ }^{26}$ The incorporation of CRSGBV into NATO's self-narrative might not have been imaginable prior to its engagement with WPS in 2007, but has come to be accepted by many of its members and partners and also within the WPS field. For example, NATO has recently been invited to address the Security Council on the issue. ${ }^{27}$ Thus, a critical feminist interrogation of narratives is necessary because, as Annick T. R. Wibben ${ }^{28}$ argues:

Security narratives, as traditionally imagined, follow a particular form to impose meaning and create value in what International Relations (IR) considers to be an anarchic world. The continual reproduction of these narratives solidifies historically developed practicesviolence practices that insist on the imposition of meanings that privilege state-centered, military forms of security. To challenge these practices, it is not only enough to propose different contents but the form of security narratives also needs to be tackled.

Relevant to our analysis then and key to developing our contribution in this area is Alister Miskimmon, Ben O'Loughlin, and Laura Roselle's ${ }^{29}$ identification of three types of strategic

\footnotetext{
${ }^{19}$ Bergman Rosamond, 'The digital politics of celebrity activism'.

${ }^{20}$ Matthew Kearns, 'Gender, visuality and violence: Visual securitization and the 2001 war in Afghanistan', International Feminist Journal of Politics, 19:4 (2017), p. 492; see also David Campbell, 'Geopolitics and visuality: Sighting the Darfur conflict', Political Geography, 26:4 (2007), p. 361.

${ }^{21}$ Annika Bergman Rosamond, 'Humanitarian relief worker Sean Penn: A contextual story', in Lisa Ann Richey (ed.), Celebrity Humanitarianism and North-South Relations: Politics, Place and Power (London: Routledge, 2015).

${ }^{22}$ Miriam Cooke, 'Saving brown women', Signs, 28:1 (2002), pp. 468-70; Shahnaz Khan, 'The two faces of Afghan women: Oppressed and exotic', Women's Studies International Forum, 44 (2013), pp. 101-09; Kearns, 'Gender, visuality and violence'; Katharine A. M. Wright, 'Telling NATO's story of Afghanistan: Gender and the alliance’s digital diplomacy', Media, War and Conflict, 12:1 (2019), pp. 87-101.

${ }^{23}$ Lene Hansen, 'Theorizing the image for security studies: Visual securitization and the Muhammad Cartoon Crisis', European Journal of International Relations, 17:1 (2011), p. 51.

${ }^{24}$ NATO, 'Joint Press Conference'.

${ }^{25}$ Miskimmon, O’Loughlin, and Roselle, Strategic Narratives.

${ }^{26}$ Ben Wellings, Serena Kelly, Bruce Wilson, Joe Burton, and Martin Holland, 'Narrative alignment and misalignment: NATO as a global actor as seen from Australia and New Zealand', Asian Security, 14:1 (2018), p. 34.

${ }^{27}$ Clare Hutchinson, 'NATO Statement in the UN Security Council on Con ICT-Related Sexual and Gender-Based Violence', NATO (2019), available at: \{https://www.nato.int/cps/en/natohq/opinions_165211.htm\} accessed 16 March 2020.

${ }^{28}$ Annick T. R. Wibben, Feminist Security Studies: A Narrative Approach (Abingdon: Routledge, 2010), p. 47.

${ }^{29}$ Miskimmon, O’Loughlin, and Roselle, Strategic Narratives.
} 
narratives: system narratives concerning the nature of the international system; identity narratives; and issue narratives. Identity narratives concern the identities of international actors and 'are in a constant process of negotiation and contestation'. ${ }^{30}$ Issue narratives 'are strategic in the sense they seek to shape the terrain on which policy discussions take place'. ${ }^{31}$ At the issue level, NATO has sought to convince their publics that 'ending' CRSGBV is possible. However, gendered violence is often represented as a problem confined to non-Western states, which serves to reinforce the masculinist Western protection logic prevalent in global politics. ${ }^{32}$ In our analysis we therefore interrogate the co-constitutive nature of the projection and reception of identity and issue narratives.

The key contribution of this article thus stems from our analysis of NATO's crafting of its identity narrative or self-narrative and importantly its wider reception, which in itself has an impact on a wider issue narrative, specifically the matter of CRSGBV. As we show below, NATO's self-narrative has sought to ground the alliance within the values laid out in its foundational treaty, rather than its militarist purpose, with an increasing focus on WPS matters. Jolie's visit added visibility and engagement with a new type of audience, lending credibility to NATO's role in an issue area that it has not engaged with as publicly before. The role of celebrity therefore underscores the importance of including visuals in our analysis in order to 'see' narratives ${ }^{33}$ and understand the meaning of their content, through their representation and interpretation. ${ }^{34}$ As we have noted, the site of reception and the role of visual representation is often overlooked in studies of strategic narratives with the notable exceptions of Rhys Crilley's ${ }^{35}$ work on identity narratives and Louise Pears on issue narratives. ${ }^{36}$ However, in focusing on the narrative NATO seeks to project and the media coverage of the visit, we show how visual representations become integral to its reception in wider celebrity and popular culture, thus shaping the strategic narrative itself. In this case through foregrounding celebrity and star power in our analysis we expose how a deeply gendered focus on Jolie's beauty and maternity is key to shaping the reception of NATO's strategic narratives.

\section{Celebrities as security actors}

A growing number of critical International Relations (IR) scholars recognise the importance of considering the constitutive effects of popular culture on world politics. ${ }^{37}$ Rather than focusing on official documents, speeches, and statements, such scholarship zooms in on photography, ${ }^{38}$ cinema, $^{39}$ fine arts and literature, ${ }^{40}$ cartoons, ${ }^{41}$ and celebrity ${ }^{42}$ as 'serious sites of

\footnotetext{
${ }^{30}$ Ibid., p. 7.

${ }^{31}$ Ibid.

${ }^{32}$ Iris Marion Young, 'The logic of masculinist protection: Reflections on the current security state', Signs, 29:1 (2003), pp. 1-26; Hannah Partis-Jennings, 'The (in)security of gender in Afghanistan's peacebuilding project hybridity and affect', International Feminist Journal of Politics, 19:4 (2017), pp. 411-25.

${ }^{33}$ Crilley, 'Seeing strategic narratives?'.

${ }^{34}$ Miskimmon, O'Loughlin, and Roselle, Strategic Narratives, p. 125.

${ }^{35}$ Crilley, 'Seeing strategic narratives?'.

${ }^{36}$ Pears, 'Ask the audience'.

${ }^{37}$ Kyle Grayson, Matt Davies, and Simon Philpott, 'Pop goes IR? Researching the popular culture-world politics continuum', Politics, 29:3 (2009), pp. 155-63; Laura J. Shepherd, Gender, Violence and Popular Culture (Abingdon: Routledge, 2012); Hamilton and Shepherd (eds), Understanding Popular Culture and World Politics in the Digital Age.

${ }^{38}$ Lene Hansen, 'How images make world politics: International icons and the case of Abu Ghraib', Review of International Studies, 41:2 (2015), pp. 263-88.

${ }^{39}$ Michael J. Shapiro, Cinematic Geopolitics (London: Routledge, 2018).

${ }^{40}$ Kyle Grayson, 'How to read Paddington Bear: Liberalism and the foreign subject in A Bear Called Paddington', The British Journal of Politics and International Relations, 15 (2013), pp. 378-93.

${ }^{41}$ Hansen, 'Theorizing the image for security studies'.

${ }^{42}$ Bergman Rosamond, 'The digital politics of celebrity activism'; Bergman Rosamond, 'Global motherhood and celebrity politics'.
} 
enquiry'. ${ }^{43}$ Hansen's work ${ }^{44}$ identifies a constitutive and interactive relationship between visuals and 'written and spoken discourses'. Key here is the position that visuals are not 'subordinated to the texts', rather, 'visuals interact with visuals' and 'texts' ${ }^{45}$ Cultural constructions such as these often contain references to imminent security threats and foreign policy challenges, and as such provide textual and visual platforms for the construction of global politics often communicated through digital channels. ${ }^{46}$ Thus, it is increasingly through popular culture that discourses and practices of peace and security are constituted and communicated. Representations of violence and security 'matter' ${ }^{47}$ and enable us to make sense of key security developments. Here we focus on textual and visual representations of celebrity in global politics, many of which are communicated through digital means. ${ }^{48}$ Our position is that the aesthetically appealing images as well as textual accounts of Angelina Jolie at NATO are effective ways in which NATO's can draw attention to its emergent self-narrative as a gender just actor committed to the eradication of CRSGBV.

Celebrity is typically defined as a distinct form of fame that is intimately linked with capitalism and enabled by mass media. ${ }^{49}$ Celebrities, are 'highly visible, famous and recognisable' and those characteristics are often mediated and constructed through mass media. ${ }^{50}$ A particular feature of contemporary celebrity culture is the ability of celebrities to communicate their ethical messages to global audiences and doing so in speedier and more visible ways than governments, NGOs, and political leaders. ${ }^{51}$ The digitalisation of politics, philanthropy, and humanitarianism has enabled the likes of Angelina Jolie, Sean Penn, George Clooney, and many others to intervene in causes that they deem of moral significance, with CRSGBV matters being a key example here. ${ }^{52}$ Thus, celebrities 'hail national and international audiences in the way only presidents, royalty and prime ministers can hope to achieve'. ${ }^{53}$ Celebrities, moreover, have 'a unique capacity to reach out to and mobilise otherwise apathetic publics, and sometimes manage to give powerful voices to the disenfranchised in society and on the world stage'. ${ }^{54}$ Whether famous individuals give voice to the unheard is a matter of debate, yet, 'people model themselves in part on the lives of those they admire. ${ }^{55}$ From this follows that visual and textual exposure to celebrity advocacy and humanitarianism could be effective in evoking interests and empathy among fans, and, often doing so through traditional and social media. ${ }^{56}$

Key here is Andrew Cooper's ${ }^{57}$ research on 'celebrity diplomacy' and his contention that there is an 'advantage of linking individual star power to a collective project' to attract attention to

\footnotetext{
${ }^{43}$ Cait Hamilton, 'World politics 2.0: An introduction', in Shepherd and Hamilton (eds), Understanding Popular Culture and World Politics in the Digital Age.

${ }^{44}$ Hansen, 'Theorizing the image for security studies', p. 53.

${ }^{45}$ Ibid.; Hansen, 'How images make world politics'; Kearns, 'Gender, visuality and violence'.

${ }^{46}$ Shepherd and Hamilton (eds), Understanding Popular Culture and World Politics in the Digital Age.

${ }^{47}$ Penny Griffin, Popular Culture, Political Economy and the Death of Feminism: Why Women are in Refrigerators and Other Stories (Abingdon: Routledge, 2015), p. 1.

${ }^{48}$ Bergman Rosamond, 'The digital politics of celebrity activism'.

${ }^{49}$ David P. Marshall, Celebrity and Power: Fame in Contemporary Culture (Minneapolis, MN: University of Minnesota Press, 1997); Hilde Van den Bulck, Celebrity Philanthropy and Activism: Mediated Interventions in the Global Public Sphere (Abingdon: Routledge, 2018).

${ }^{50}$ Van den Bulck, Celebrity Philanthropy and Activism, pp. 28-9.

${ }^{51}$ Bergman Rosamond, 'The digital politics of celebrity activism'; Mark Wheeler, Celebrity Politics (Cambridge: Polity Press, 2013).

${ }^{52}$ Bergman Rosamond, 'The digital politics of celebrity activism'; Natalie Florea Hudson and Alexandra Cosima Budabin, 'When advocacy securitizes non-state actors and the circulation of narratives around sexualized violence in conflict', in Michael J. Butler (ed.), Securitization Revisited: Contemporary Applications and Insights (Abingdon: Routledge, 2019).

${ }^{53}$ Marshall, Celebrity and Power, p. 3; see also Van den Bulck, Celebrity Philanthropy and Activism.

${ }^{54}$ David Marsh, Paul 't Hart, and Karen Tindall, 'Celebrity politics: The politics of the late modernity?', Political Studies Review, 8:3 (2010), p. 333.

${ }^{55}$ Fred Inglis, A Short History of Celebrity (Princeton, NJ: Princeton University Press, 2010), p. 13.

${ }^{56}$ Van den Bulck, Celebrity Philanthropy and Activism.

${ }^{57}$ Cooper, Celebrity Diplomacy, p. 7.
} 
global injustices. The boundaries between politics, diplomacy, and celebrity are increasingly blurred, giving rise to new modes of diplomacy and advocacy that at times replace 'public action in favor of personal diplomacy'. ${ }^{58}$ However, celebrity diplomacy does not replace politics but rather 'complements and challenges traditional forms of statecraft and diplomacy in ways that are not without controversy'. ${ }^{59}$ Indeed, beyond diplomacy at a global level 'celebrities have become increasingly important in international development assistance'. ${ }^{60}$ Their ethical legitimacy, in part at least, is derived from the recognition of their potential impact among national governments, politicians, and international organisations such as the UN. ${ }^{61}$ While celebrities often work on their own initiative, setting up foundations or visiting conflict-affected areas, ${ }^{62}$ they also are invited by a variety of actors to lend their names and fame to certain global issues. ${ }^{63}$ National governments have drawn on celebrity in shaping their own identity narratives, one example being singer Rihanna's appointment as an Ambassador by Barbados to promote the nation's education, tourism, and investment. ${ }^{64}$ NGOs also frequently use celebrities to shape issue narratives, drawing media attention to their cause and to raise funds. ${ }^{65}$

Yet, the role that celebrities perform in global governance is not straightforward since often they appear to be 'far from altruistic', but rather 'ideological', 'self-serving', and promoting the 'celebrity brand' and embedding the 'very global inequality it seeks to redress'. ${ }^{66}$ As such, they inspire 'narcissistic solidarity obsessed with our own emotions' rather than 'suffering others' ${ }^{67}$

The work of Alexandra Budabin and Lisa Ann Richey on celebritisation of conflict in the Democratic Republic of Congo, ${ }^{68}$ the study by Natalie Florea Hudson and Alexandra Budabin $^{69}$ of the role of non-state actors in securitising sexual violence in conflict and Annika Bergman Rosamond's engagement with celebrity anti-war and interventionism ${ }^{70}$ have made important contributions to our understanding of celebrities as security actors. Yet, less attention has been paid to celebrities' explicit support for (political-) military actors such as NATO. Our critical feminist study of Angelina Jolie's celebrity partnership with NATO, then, contributes to widening the scope of our understanding of the role and value of celebrity to global security structures and shaping both issue and identity narratives. Our specific intention here is to investigate how Angelina Jolie's celebrity status and associated humanitarianism can contribute to the legitimisation of NATO's strategic narrative. Here we do not determine the ethical legitimacy of Jolie's support for NATO's role in promoting CRSGBV matters, rather our ambition is to bring light to celebrities' role in global security politics (or lack thereof).

\footnotetext{
${ }^{58}$ Lilie Chouliaraki, The Ironic Spectator: Solidarity in the Age of Post-Humanitarianism (Cambridge: Polity Press, 2013), p. 79; Wheeler, Celebrity Politics.

${ }^{59}$ Michelle Pace and Annika Bergman Rosamond, 'Political legitimacy and celebrity politicians: Tony Blair as Middle East envoy 2007-2015', Middle East Critique, 27:4 (2018), pp. 383-98; see also Benwell, Dodds, and Pinkerton, 'Celebrity geopolitics'.

${ }^{60}$ Lisa Ann Richey and Alexandra Cosima Budabin, 'Celebritizing conflict: How Ben Affleck sells the Congo to Americans', Humanity: An International Journal of Human Rights, Humanitarianism and Development, 7:1 (2016), p. 27.

${ }^{61}$ Bergman Rosamond, 'Global motherhood and celebrity politics'.

${ }^{62}$ Bergman Rosamond, 'Humanitarian relief worker Sean Penn'.

${ }^{63}$ Davies and True, 'Norm entrepreneurship in foreign policy'.

${ }^{64}$ 'Rihanna appointed as ambassador by Barbados', BBC News (2018), available at: \{https://www.bbc.co.uk/news/worldlatin-america-45609656\} accessed 5 January 2021.

${ }^{65}$ Van den Bulck, Celebrity Philanthropy and Activism.

${ }^{66}$ Ilan Kapoor, Celebrity Humanitarianism the Ideology of Global Charity (London: Routledge, 2013), p. 1.

${ }^{67}$ Chouliaraki, The Ironic Spectator, p. 79; Dan Brockington, Celebrity Advocacy and International Development (Oxford: Routledge, 2014), p. 23.

${ }^{68}$ Richey and Budabin, 'Celebritizing conflict'.

${ }^{69}$ Hudson and Budabin, 'When advocacy securitizes'.

${ }^{70}$ Annika Bergman Rosamond, 'The cosmopolitan-communitarian divide and celebrity anti-war activism', in Liza Tsaliki, Christos A. Frangonikolopoulos, and Asteris Huliaras (eds), Transnational Celebrity Activism in Global Politics Changing the World? (Chicago: Chicago University Press, 2011).
} 


\section{Contesting Women, Peace and Security as an issue narrative}

Emerging from United Nations Security Council Resolution (UNSCR) 1325, adopted in 2000, and subsequently reinforced through the adoption of nine further related resolutions, ${ }^{71}$ the WPS agenda was ground-breaking. It calls for women's empowerment and involvement in peace negotiations and peacekeeping missions to enhance the prospects for long-lasting peace and security, while acknowledging women's specific vulnerabilities. The issue of CRSGBV is integral to the agenda and envisaged as a threat to international peace and security.

Despite its pronounced commitment to gender-just peace, the WPS agenda contains mechanisms, discourses, and practices, which, at times, are inconsistent with feminist commitments to demilitarisation and peace, as numerous feminist scholars have noted. ${ }^{72}$ Further, this language can actually reinforce militarist and Western imperialist positions. ${ }^{73}$ Yet, as Karin Aggestam and Annika Bergman Rosamond note, there are 'a variety of political discourses present in national and international debates on the WPS agenda', providing 'arenas for collaboration between non-military and military actors, which challenge and contest the use of militaristic language and practice. ${ }^{74}$ It is an imperative therefore to consider whether the implementation of the agenda has 'resulted in narrow, self-interested, and even militaristic responses to complex social problems? ${ }^{75}$ thus shaping the issue narrative.

On CRSGBV specifically, WPS frames the issue within racialised language by frequently representing men from conflict-affected areas as the predominate perpetrators, serving to deflect from the prevalence of such violence in 'peacetime' states ${ }^{76}$ or among peacekeepers. ${ }^{77}$ Furthermore, the reductive character of WPS frames the issue as an individual, rather than systemic problem, and women's participation in peacebuilding as a means to address the issue. ${ }^{78}$ Moreover, adding women and stirring, in a liberal sense, does not necessarily disrupt the gender order of military institutions, but rather ensures the sedimentation of masculinised norms that are in turn linked to militarism. ${ }^{79}$ This narrative also mandates a state-based response underpinned by an assumption that restoring state authority and bringing perpetrators to justice will end CRSGBV. ${ }^{80}$ This in turn echoes NATO's own problematised approach to CRSGBV, understood as a 'weapon of war', focusing on recruiting enough women to NATO forces on the premise this will support their transformation. $^{81}$ Next, we examine NATO's self-narrative as a WPS actor before considering what the addition of Jolie and an increased emphasis on celebrity, aesthetics and the visuals might do to that story and the wider issue narrative of WPS and CRSBV specifically.

\footnotetext{
${ }^{71}$ The ten WPS resolutions are: 1325 (2000); 1820 (2009); 1888 (2009); 1889 (2010); 1960 (2011); 2106 (2013); 2122 (2013); 2242 (2015), 2467 (2019), and 2493 (2019).

${ }^{72}$ Sam Cook, 'Security Council Resolution 1820: On militarism, flashlights, raincoats, and rooms with doors: A political perspective on where it came from and what it adds', Emory International Law Review, 23 (2009), pp. 125-40; Laura J. Shepherd, 'Making war safe for women? National Action Plans and the militarisation of the Women, Peace and Security agenda', International Political Science Review, 37:3 (2016), pp. 324-35; Karin Aggestam and Annika Bergman Rosamond, 'Re-politicising the gender-security nexus: Sweden's feminist foreign policy', European Review of International Studies, 5:3 (2018).

${ }^{73}$ Soumita Basu, 'The Global South writes 1325 (too)', International Political Science Review, 37:3 (2016), pp. 62-374.

${ }^{74}$ Aggestam and Bergman Rosamond, 'Re-politicising the gender-security nexus', p. 35.

${ }^{75}$ Natalie Florea Hudson, 'Securitizing women's rights and gender equality', Journal of Human Rights, 8:1 (2009), pp. 5370.

${ }^{76}$ Gina Heathcote, 'Security Council Resolution 2242 on Women, Peace and Security: Progressive gains or dangerous development?', Global Society, 32:4 (2018), p. 380.

${ }^{77}$ Marsha Henry, 'Peacexploitation? Interrogating labor hierarchies and global sisterhood among Indian and Uruguayan female peacekeepers', Globalizations, 9:1 (2012), pp. 15-33.

${ }^{78}$ Heathcote, 'Security Council Resolution 2242 ', p. 380.

${ }^{79}$ Annica Kronsell, Gender, Sex and the Postnational Defense: Militarism and Peacekeeping (New York: Oxford University Press, 2012).

${ }^{80}$ Sara Meger, 'The fetishization of sexual violence in international security', International Studies Quarterly, 60:1 (2016), p. 153.

${ }^{81}$ Wright, Hurley, and Ignacio Ruiz, NATO, Gender and the Military, p. 122.
} 


\section{NATO's self-narrative: A WPS actor in the making}

While the self-identity of NATO primarily is that of a political-military alliance, it has engaged with gender issues for some time, pre-dating its adoption of a policy on WPS in $2007 .^{82}$ Yet, it is only recently that this work has moved from the margins to the epicentre of the alliance, which has changed the way the alliance projects itself as an actor in international politics through its strategic narrative. ${ }^{83}$ As Matthew Hurley argues, storytelling has been central to institutionalising WPS at NATO, serving to 'reinforce a wider narrative of positive progression and inevitable harmony between the Women, Peace and Security agenda and NATO "values" constructed by the alliance; a narrative that is premised on NATO's understanding of itself as a key, responsible international actor ${ }^{84}$ Such an engagement with WPS has contributed to a core part of NATO's public face, the promotion of democracy and freedom across the world, ${ }^{85}$ with, as Katharine A. M. Wright argues, support for WPS being part of that quest. ${ }^{86}$

Key to NATO's evolving self-narrative is its embrace of new forms of digital communication, with NATO responding to the proliferation of social media and a turn to digital diplomacy in global politics. ${ }^{87}$ For example, social media has been used to visually project a select few senior women in NATO, belying the gendered reality of an organisation dominated by men in decisionmaking positions. ${ }^{88}$ This self-narrative has also been defined by the distinct masculinist protection logic, with NATO justifying its military interventionism on gendered grounds. ${ }^{89}$

NATO's response is in part reflective of the constraints of a multilateral institution built on consensus decision-making, limited by its members' priorities, and sensitive not to implicate themselves as perpetrators..$^{90}$ NATO's initial policy position on WPS in 2007 made no mention of sexual violence in conflict, although it was introduced in the resulting military command. ${ }^{91}$ BI-Strategic Command 40-1 narrates NATO as a protector of women from CRSGBV, while upholding the alliance's standards in operational conduct on the ground. ${ }^{92}$ This narration is carried through in its 2011 revised policy, which describes how the WPS resolutions make provision for responses to CRSGBV, but it does not outline NATO's specific responsibilities. ${ }^{93}$ The 2014 revision of NATO's WPS policy and action plan detail for the first time NATO actions on CRSGBV, including the development of military guidelines and their integration into operational

\footnotetext{
${ }^{82}$ Katharine A. M. Wright, 'NATO's adoption of UNSCR 1325 on Women, Peace and Security: Making the agenda a reality', International Political Science Review, 37:3 (2016), pp. 350-61; Wright, Hurley, and Ignacio Ruiz, NATO, Gender and the Military.

${ }^{83}$ Wright, 'Telling NATO's story of Afghanistan'; Wright, Hurley, and Ignacio Ruiz, NATO, Gender and the Military, p. 14

${ }^{84}$ Matthew Hurley, 'Watermelons and weddings: Making Women, Peace and Security "relevant" at NATO through (re)telling stories of success', Global Society, 32:4 (2018), pp. 436-56.

${ }^{85}$ Kuus, “Love, peace and Nato"', p. 269; Merje Kuus, 'Cosmopolitan militarism? Spaces of NATO expansion', Environment and Planning A, 41:3 (2009), pp. 545-62.

${ }^{86}$ Wright, 'NATO's adoption of UNSCR 1325'; Wright, 'Telling NATO's story of Afghanistan'; see also: Wright, Hurley, and Ignacio Ruiz, NATO, Gender and the Military, p. 108.

${ }^{87}$ G. R. Dimitriu, 'Winning the story war: Strategic communication and the conflict in Afghanistan', Public Relations Review, 38:2 (2012), p. 203.

${ }^{88}$ Wright, Hurley, and Ignacio Ruiz, NATO, Gender and the Military, p. 31.

${ }^{89}$ Hurley, 'Watermelons and weddings'; Wright, 'Telling NATO's story of Afghanistan'; Wright, Hurley, and Ignacio Ruiz, NATO, Gender and the Military.

${ }^{90}$ Laura Hebert, 'Analyzing UN and NATO responses to sexual misconduct in peacekeeping operations', in Annica Kronsell and Erika Svedberg (eds), Making Gender, Making War Violence, Military and Peacekeeping Practices (Abingdon: Routledge, 2012).

${ }^{91}$ Wright, Hurley, and Ignacio Ruiz, NATO, Gender and the Military, p. 120.

${ }^{92}$ NATO, 'Bi-Strategic Command Directive 40-1 Integrating UNSCR 1325 and Gender Perspectives in the NATO Command Structure including Measures for Protection during Armed Conflict' (2009), available at: \{http://www.nato.int/ nato_static/assets/pdf/pdf_2009_09/20090924_Bi-SC_DIRECTIVE_40-1.pdf\} accessed 12 December 2012.

${ }^{93}$ NATO, 'NATO/EAPC policy for implementing UNSCR 1325 on Women, Peace and Security, and Related Resolutions' (2011), available at: \{http://www.nato.int/cps/en/SID-25EE1764- ED25FDD4/natolive/official_texts_76395.htm?selected Locale=en $\}$ accessed 3 January 2013
} 
planning, ${ }^{94}$ with the military guidelines adopted in $2015 .{ }^{95}$ Hence at the time of Jolie's visit, NATO was making some inroads to address CRSGBV, but lagged behind the wider international impetus to address CRSGBV. It also was not actively seeking to project its understanding of CRSGBV in shaping the wider issue narrative.

It is worth noting here that Jolie's visit coincided with the first month in office of Clare Hutchinson, newly appointed to the role of NATO Secretary General's Special Representative on WPS. Hutchinson's address to the UN Security Council in April 2019 on CRSGBV contrasts significantly with the language of both Jolie and Stoltenberg just 15 months prior. It was a departure from NATO's previous (and Jolie's own) narrow focus on CRSGBV as a 'tactic of war', rather she argues that 'sexual violence stems from fundamental gender inequalities. Focussing on solely protective and preventative solutions is limited and insufficient. ${ }^{.96}$ Hutchinson's intervention at the Security Council shows the importance but also the limits of individuals in shaping institutional narratives from within. It should be noted that beyond Hutchinson's intervention, NATO's policy commitments continue to narrowly define sexual violence in conflict as a weapon of war. This apparent significant departure and Hutchinson's leadership on WPS at NATO may indicate why Jolie did not return to NATO in the 'coming months and years' as she had stated she would. ${ }^{97}$ And while Jolie was billed to return to NATO (virtually) for a Digital Dialogue on Conflict Related Violence in June 2020 she failed to show at the last minute. ${ }^{98}$ Another explanation could be Jolie's view of how NATO was approaching the issue. Prior to her successful partnership with UK Foreign Secretary William Hague on PSVI, Jolie initially refused the invitation to engage because of a fear it would turn into 'a lot of talking ... when something very practical had to be done'. ${ }^{99}$

\section{Angelina Jolie's 2018 visit to NATO}

A critical feminist reading of Jolie is integral to understanding how her star power, and the issues or institutions she lends it to, shapes the way in which strategic narratives are received. Like a number of famous people, Angelina Jolie possesses a private and public self, with the latter being a 'staged activity, in which the human actor presents a front or a face to others while keeping a significant portion of the self in reserve'. ${ }^{100}$ Of course no single story can capture the persona of Angelina Jolie, rather it is a composite of glamorous mega-mainstream star, influential humanitarian, power mom, part of a celebrity couple and radical personality'. ${ }^{101}$ Several scholars have attributed her sense of obligation to her dual role as a mother, combining the maternal care of her children with her compassionate approach to women and children and other vulnerable categories in need. She is what Annika Bergman Rosamond defined as a 'global mother', which is also a term used by Lisa Ann Richey and Dan Brockington ${ }^{102}$ in describing her maternal

\footnotetext{
${ }^{94}$ NATO, 'NATO/EAPC Action Plan for the Implementation of the NATO/EAPC Policy on Women, Peace and Security' (2014), available at: \{http://www.nato.int/nato_static/assets/pdf/pdf_2014_06/20140626_140626-wps-action-plan.pdf\} accessed 29 August 2017.

${ }^{95}$ NATO, 'Military Guidelines on the Prevention of, and Response to, Conflict Related Sexual and Gender-Based Violence' (2015), available at: \{http://www.nato.int/issues/women_nato/2015/MCM-0009-2015_ENG_PDP.pdf\} accessed 20 October 2016.

${ }^{96}$ Hutchinson, 'NATO Statement'.

${ }^{97}$ NATO, 'Joint Press Conference'.

${ }^{98}$ Author's attendance as an audience member at the Digital Dialogue.

${ }^{99}$ Julian Borger, 'Angelina Jolie and William Hague form unlikely double act to tackle rape in war', The Guardian (2013), available at: \{http://www.theguardian.com/politics/2013/mar/27/angelina-jolie-william-hague-war\}.

${ }^{100}$ Chris Rojek, Celebrity (London: Reaction Books, 2001), p. 11; see also Van den Bulck, Celebrity Philanthropy and Activism, p. 117.

${ }^{101}$ Anne Jerslev, 'Talking about Angelina: Celebrity gossip on the Internet', Nordic Journal of Media Studies, 12:1 (2014), p. 109; see also Bergman Rosamond, 'The digital politics of celebrity activism'.

${ }^{102}$ Bergman Rosamond, 'The digital politics of celebrity activism'; Bergman Rosamond, 'Global motherhood and celebrity politics'; Lisa Ann Richey and Dan Brockington, 'Celebrity humanitarianism: Using tropes of engagement to understand North/South relations', Perspectives on Politics, 18:1 (2020), pp. 43-59; Mary Mostafanezhad, 'Angelina Jolie and the everyday
} 
care beyond borders. Jolie's pursuits of global motherhood then are rooted in 'her lived experiences as a mother of six children (biological and adopted) combined with her mega stardom and privileged position in the world economy', which 'place her well to intervene in discourses and practices on global justice, rights and violence'. Her performance of maternal care in global politics has often taken the shape of support for women and girls suffering at the hands of forceful displacement sexual violence in conflict. ${ }^{103}$ What is more, Jolie's commitment to the eradication of CRSGBV is situated within her preference for cosmopolitan conceptions of global obligation and face-to-face encounters. ${ }^{104}$ In her words:

I have met survivors from Afghanistan and Somalia, and they are just like us with one crucial difference. We live in safe countries with doctors we can go to when we're hurt, police we can turn to when we're wronged, and institutions that protect us. They live in refugee camps ... in areas where there is no law, no protection, and not even the hope of justice. They struggle to keep their children safe, and if they admit to being raped, they are likely to face more violence and social rejection. ${ }^{105}$

As an actor Jolie has appeared in blockbusters and directed her own films, including In the Land of Blood and Honey (covering CRSGBV in the Bosnian War). Aside from her artistic work, Angelina Jolie is known for her roles as a UNHCR Goodwill Ambassador (2001-12) and, more recently, as a Special Envoy to the UN High Commissioner for Refugees (2012-present). She also launched and co-led the UK's Preventing Sexual Violence in Conflict Initiative (PSVI) with former Foreign Secretary William Hague, ${ }^{106}$ and is now a Professor of Practice at the London School of Economics teaching on the MA in Women, Peace and Security. We contend here that the legitimacy of Jolie, in part at least, has derived from her numerous and varied engagements with the issue of sexual violence in conflict, which can be of value to other more conventional security actors who may lack credibility in the area of WPS, such as NATO. Moreover, that the value and subsequent reception of such engagement has to be understood against the wider gendered backdrop of her positioning as a 'global mother'. ${ }^{107}$

Thus, Jolie is highly visible in the entertainment industry and in global politics. That visibility, moreover, has been amplified by the digitalisation of celebrity diplomacy and politics, ensuring that visuals portraying Jolie, either on her humanitarian trips to conflict zones, or in her official UNHCR role are dispersed globally. ${ }^{108}$ The digital circulation of images of Jolie promoting the eradication of CRSGBV and issues pertaining to the ongoing global refugee crisis during her many overseas trips, ${ }^{109}$ we argue, is key to securing the wide reception within popular culture of her visit to NATO. Such media footage mixes projections of Jolie as a (white) saviour and a global mother supporting survivors of sexual violence, with imagery of her 'hanging out' with the likes of former British Foreign Secretary William Hague and now NATO Secretary General Jens Stoltenberg (Figure 1). Her legitimacy then as a humanitarian actor is underpinned by racialised and gendered logics as well as Jolie's privileged position in global politics. ${ }^{110}$ The invitation

geopolitics of celebrity humanitarianism in a Thailand-Burma border town', in Richey (ed.), Celebrity Humanitarianism and North-South Relations, pp. 27-47.

${ }^{103}$ Bergman Rosamond and Gregoratti, 'Neoliberal turns in global humanitarian governance'; Bergman Rosamond, 'The digital politics of celebrity activism'; Davies and True, 'Norm entrepreneurship in foreign policy'.

${ }^{104}$ Bergman Rosamond, 'The digital politics of celebrity activism'; Bergman Rosamond, 'Global motherhood and celebrity politics'; Mostafanezhad, 'Angelina Jolie and the everyday geopolitics'.

${ }^{105}$ Angelina Jolie, 'Remarks from the UN High Commissioner for Refugees Special Envoy Angelina Jolie', 12 June 2014.

${ }^{106}$ Davies and True, 'Norm entrepreneurship in foreign policy'.

${ }^{107}$ Bergman Rosamond, 'Global motherhood and celebrity politics'.

${ }^{108}$ Van den Bulck, Celebrity Philanthropy and Activism.

${ }^{109}$ Bergman Rosamond, 'The digital politics of celebrity activism'; Bergman Rosamond, 'Global motherhood and celebrity politics'.

${ }^{110}$ Bergman Rosamond, 'Global motherhood and celebrity politics'. 


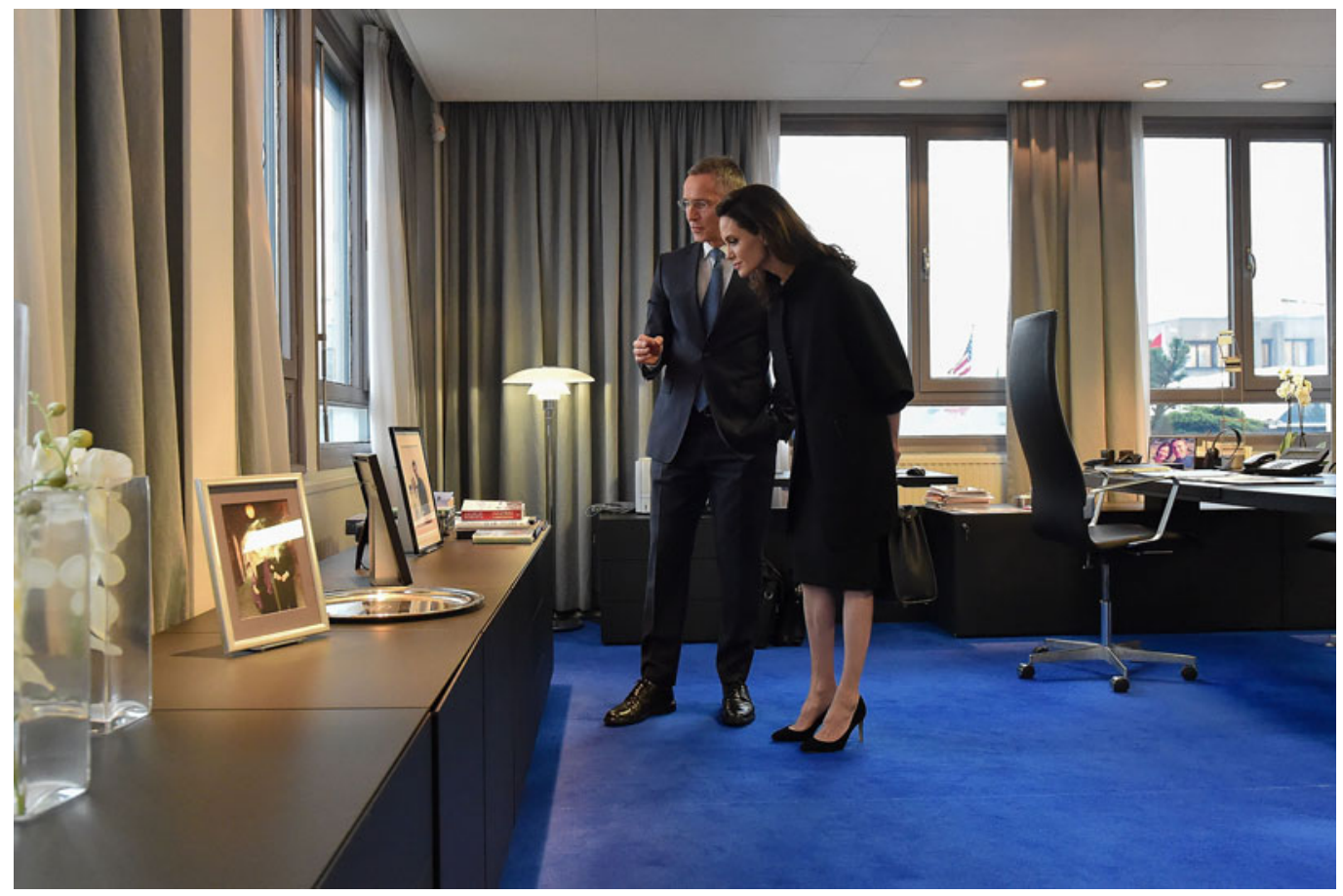

Figure 1. Angelina Jolie with NATO Secretary General Jens Stoltenberg in his office.

Source: NATO, 'Visit to NATO by the Special Envoy for the United Nations High Commissioner for Refugees' (2018), available at: \{https:// www.nato.int/cps/en/natohq/photos_151258.htm\} accessed 11 April 2018. Image used under NATO's 'fair use' policy: \{https://www.nato. int/cps/en/natohq/68162.htm\}.

to NATO in 2018 has contributed to securing her status as one of the world's most powerful celebrity diplomats. Yet, we should ask whether somebody like Jolie really challenges the current international security structure because 'most celebrities do not fundamentally challenge statist practices and discourses of sovereign integrity and capitalism ... but reproduce these through their privileged position in celebrity society." ${ }^{111}$ In what follows we turn to Jolie's engagements with NATO, seeking to unpack the reasons for the alliance's decision to join forces with the star and drawing attention to the relatively short-lived nature of that partnership, as well as the often underappreciated complexity of CRSGBV issues.

The first thing to note is that NATO does not have a celebrity liaison office nor have there been previous engagements with global celebrity on the scale of Angelina Jolie's visit to the alliance. ${ }^{112}$ The impetus for Jolie's engagement with NATO is not known so it is unclear whether the drive came from Jolie or NATO. ${ }^{113}$ At this stage we should also note that though we initially expected

\footnotetext{
${ }^{111}$ Bergman Rosamond, 'The digital politics of celebrity activism', p. 105.

${ }^{112}$ While there have been celebrity visits to NATO, these have not been from globally recognised stars, nor visits aimed at drawing attention to NATO from a global audience. For example, in 2005 the Eurovision song contest winner Ruslana and a group of Ukrainian celebrities visited NATO HQ and met the Secretary General (NATO, 2005). The purpose of the visit was to examine 'how celebrities could help in Ukraine's membership aspirations and work to break down lingering Cold War stereotypes' (NATO, 2005). There was neither press conference nor wider media coverage outside Ukraine.

${ }^{113}$ Given NATO has no track record of engaging global celebrities, it seems likely it relied on an individual within NATO to make the meeting possible. The approach to Jolie did not come via the WPS Office given the post had been effectively vacant prior to Clare Hutchinson taking up the role in January 2018 coinciding with Jolie's visit to NATO. The US Ambassador to NATO is not present in any of the smaller meetings and if the approach had come through the US delegation (or any other delegation) we could expect them to be a visible presence accompanying Jolie. A person we do find present in all
} 
that Jolie's visit would mark the start of a long-term relationship between her and NATO, it turned out to be a short lived collaboration. Apart from her 2018 visit as far as we know no other visit has taken place and, as we have discussed, while she was billed as returning to NATO in June 2020 for a virtual event she was a last minute no-show. At the joint NATO press conference Jolie articulated that 'I am very honoured that I will be working with him [the Secretary General] over the coming months and years' and 'there is a lot more work to be done and so one of the countries we [NATO and Jolie] have been focusing on, possibly being one of our first to visit, is Afghanistan'. ${ }^{114}$ Given Jolie's frequent appearance at the UN as well as her long-term commitment to the eradication of sexual violence in conflict and the destiny of the world's refugees it is a little surprising that only one such high-profile visit took place. That a long-term partnership did not come to pass tells us something about both NATO and the role of celebrity in security. However, it does not mean that supporting particular causes across organisational and national contexts has no constitutive effects. The frequency with which images of Jolie at NATO appeared in digital and social media and continue to do so leads us to conclude that the alliance's efforts have not been insignificant, lending evidence to the wider 'celebrification' of NATO's WPS work and further contributing to shaping NATO's self-narrative, as well as legitimising NATO's projection of CRSGBV as an issue narrative.

The invocation of celebrity to engage with an issue narrative is significant both because, as discussed above, NATO engaged relatively late with CRSGBV, but also because CRSGBV is not a global issue without controversy; it is messy and contested. ${ }^{115}$ This provides a challenge for policymakers who inevitably rely on simplification in dealing with the issue ${ }^{116}$ with more nuanced understandings of CRSGBV far less likely to capture headlines. ${ }^{117}$ It also provides an opportunity for an intervention by an actor such as NATO to shape the issue narrative concerning CRSBV, and at the same time their own self-narrative, with simpler understandings more likely to capture popular cultural imaginaries. A partnership with celebrity further facilitates such action and while Jolie is often elevated as an expert on gender justice and repression, her preference for rapid solutions, at times, appears to be divorced from more long-term thinking, even if her 'star power' has elevated the issue to global attention. ${ }^{118}$ Her rhetoric then is located within a wish to end sexual violence in conflict 'once and for all', though the issue is complex and demands long-term structural solutions and the disruption of global and domestic patriarchy. For example, the UK's PSVI, spearheaded by Jolie and Hague, was informed by a 'limited and simplistic framing of what is and what is not', ${ }^{119}$ with the lack of leadership, strategy, and funding leading to a 'risk that programming inadvertently causes harm to survivors. ${ }^{20}$ Yet, whenever Jolie speaks the world has a tendency to listen, regardless of the shortcomings of some of the projects (or organisations) that she pairs up with.

\footnotetext{
of the meetings bar one is then-Deputy Secretary General and US Diplomat Ambassador Rose Gottemoeller, who is also seen in video footage taking the lead in introducing Jolie to other NATO Officials (Hutchinson, 'NATO Statement in the UN Security Council'). She is also a known supporter of the WPS agenda and so uniquely positioned within NATO at that time to make the connection.

${ }^{114}$ NATO, 'Joint Press Conference'.

${ }^{115}$ Harriet Gray and Anja K. Franck, 'Refugees as/at risk: The gendered and racialized underpinnings of securitization in British media narratives', Security Dialogue, 50:3 (2019), p. 201.

${ }^{116}$ Maria Eriksson Baaz and Maria Stern, Sexual Violence as a Weapon of War? Perceptions, Prescriptions, Problems in the Congo and Beyond (London: Zed Books, 2013), p. 4.

${ }^{117}$ Gray and Franck, 'Refugees as/at risk', p. 201.

${ }^{118}$ Cooper, Celebrity Diplomacy, pp. 34-5; Mark Wheeler, 'Celebrity diplomacy: United Nations' goodwill ambassadors and messengers of peace', Celebrity Studies, 2:1 (2011), p. 15.

${ }^{119}$ Gray and Franck, 'Refugees as/at risk', p. 201.

${ }^{120}$ Independent Commission for Aid Impact, 'The UK's Preventing Sexual Violence in Conflict Initiative' (2020), available at: $\quad$ https://icai.independent.gov.uk/wp-content/uploads/The-UKs-preventing-sexual-violence-in-conflict-initiative.pdf accessed 27 January 2020.
} 
Angelina Jolie's visit to Brussels in 2018 marked a change in NATO's public diplomacy practices through engaging global celebrity for the first time, while adding visibility and recognition to its work on CRSGBV issues and providing an opening for NATO to shape the issue narrative as well as its own self-narrative. Given that NATO had in 2018 trailed behind wider moves to address sexual violence in conflict, teaming up with Angelina Jolie, whose involvement in the eradication of CRSGBV exceeds that of NATO, appeared to be a smart move. To reconstitute its own self-narrative, NATO made productive use of the publicity surrounding Jolie's visit through the use of a live-streamed press conference, video shoots, and photo opportunities (See, for example, Figures 1-6). The story telling surrounding Jolie's visit was preceded by a joint op-ed that NATO Secretary General Jens Stoltenberg and Jolie published in The Guardian. As noted previously, media coverage of Jolie's also featured in outlets such as the Daily Mail Online, PopSugar, and People. Jolie's presence at NATO could therefore be viewed as smart diplomacy, and an important step in retelling the story about the alliance using celebrity and online outlets to engage a global audience. What is more, by retelling its identity narrative and by adding celebrity to its plot NATO has sought to attract audiences that otherwise would have little knowledge of what NATO is or does. ${ }^{121}$ The coverage of Jolie's appearances at NATO followed the same logic as her appearances elsewhere with visuals being employed to capture global audiences and secure the wider reception of the strategic narrative. As Roland Bleiker ${ }^{122}$ argues 'images and visual artefacts do things. They are political forces in themselves. They often shape politics as much as they depict it.' The highly visual visit was therefore an exercise in what we term the 'beautifying' of NATO through invoking celebrity and aesthetically pleasing visuals, and using social media effectively in so doing.

The press release and 74 'behind-the-scenes' images NATO released of the visit ${ }^{123}$ emphasise both the importance of visuals, but also give us a preview of Jolie's itinerary. In a similar vein to her UN field visits, Jolie met with senior officials in a variety of formats, including a one-to-one with the Secretary General Jen Stoltenberg in his private office, meeting later with Deputy Secretary General Rose Gottemoeller and Supreme Allied Commander Europe General Curtis Scaparrotti to be briefed by NATO's gender advisors in Afghanistan and Kosovo via teleconference. ${ }^{124}$ Jolie also met with the NATO Special Representative on WPS Clare Hutchinson and the Chief of the International Military Staff Office of the Gender Advisor Magdalena Dvorakova (Figure 2).

Significantly, Jolie participated in a specially convened joint meeting of NATO's highest decision-making bodies; the North Atlantic Council and Military Committee, which 'focused on NATO's efforts to prevent sexual and gender-based violence' (Figures 3 and 4). At the meeting she sat next to the Secretary General, which is something largely unprecedented. Unsurprisingly given her star status, her walk around NATO headquarters attracted attention from staff who were quick to snap photographs of Jolie, and take 'selfies' of themselves on their mobile phones, adding a new dimension to the coverage and reception of the visit on social media (as a number of NATO Officials commented on Twitter) (Figure 5). The joint press conference with Stoltenberg was also given in front of a packed press gallery (Figure 6).

While the WPS agenda, (and more so CRSGBV issues) are highly contentious and political, the partnership between Jolie and NATO is presented as frictionless and depoliticised, or as People magazine described 'the latest stop in a whirlwind tour [by Jolie] that has combined business with pleasure'. ${ }^{125}$ Whereas Jolie championed NATO's role in her visit and surrounding

\footnotetext{
${ }^{121}$ Kuus, “'Love, peace and Nato"'; Kuus, 'Cosmopolitan militarism?'.

${ }^{122}$ Roland Bleiker, 'Mapping visual global politics', in Roland Bleiker (ed.), Visual Global Politics (Abingdon: Routledge, 2018), p. 3.

${ }^{123}$ NATO 'Visit to NATO'.

${ }^{124}$ NATO, 'Joint Press Conference'.

${ }^{125}$ Phil Boucher and Peter Mikelbank, 'Angelina Jolie urges NATO to target sexual violence in conflict zones', People (2018), available at: \{https://people.com/movies/angelina-jolie-urges-nato-to-target-sexual-violence-in-conflict-zones/\} accessed 26 February 2020.
} 


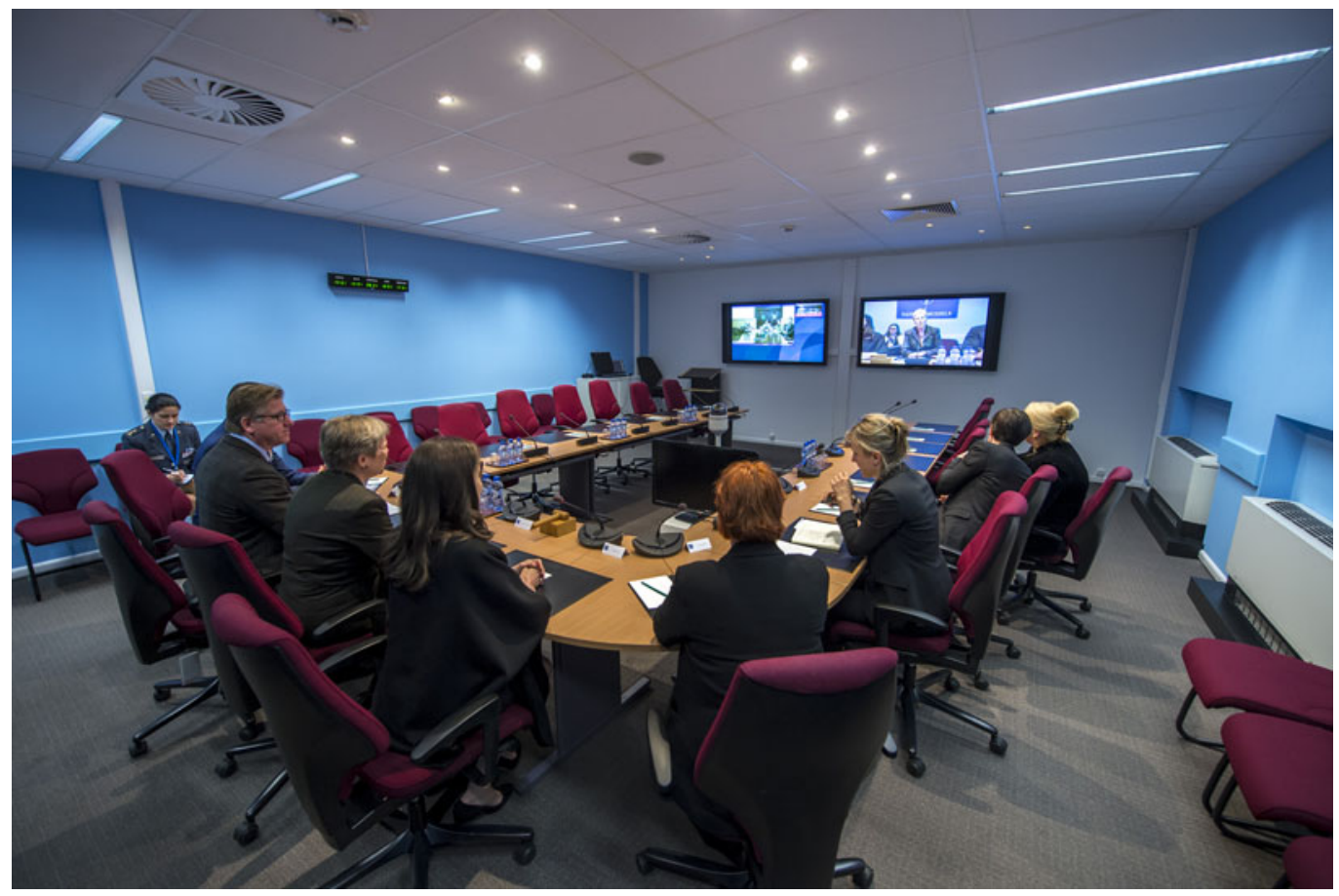

Figure 2. Angelina Jolie and Deputy Secretary General Rose Gottemoeller attend a teleconference with mission commanders and gender advisors, including Secretary General's Special Representative on Women, Peace and Security Clare Hutchinson and Chief of the IMS Office of the Gender Advisor Magdalena Dvorakova.

Source: NATO, 'Visit to NATO'. Image used under NATO's 'fair use' policy: \{https://www.nato.int/cps/en/natohq/68162.htm\}.

publicity, she was quick to distance herself where a less positive and progressive image of NATO was presented. For example, a question on addressing impunity given 'NATO is seen in large parts of the world as the vehicle of American imperialism', led Jolie to respond that she is

joining NATO as a humanitarian. I am here to be working, you know I am not a military personnel but I am here to help to work on the side of where NATO does training that affects their relationship to the civilians on the ground and their accountability to the civilians on the ground and their impact. ${ }^{126}$

Her interventions sidestep the question at hand and conveys the idea that NATO is somewhat detached from those who suffer on the ground. It rests on an assumption that she, though a celebrity, is more connected to the survivors and victims of sexual violence. This discursive logic lacks reflection of Jolie's own location within privilege, power, and the colonial and gendered logics of Western humanitarianism. ${ }^{127}$ Further, she upholds the masculinist protection logic that defines states' participation in NATO-led military operations for the purpose of saving sufferers beyond borders. This contributes to the projection of a depoliticised reading of the CSRGBV issue narrative, ${ }^{128}$ itself necessary to support NATO's self-narrative as a gender just military actor.

Our focus here is not on Jolie's activism but what this partnership, however fleeting, means for NATO's self-narrative, potential to shape CRSGBV as an issue narrative, and importantly its

\footnotetext{
${ }^{126}$ NATO, 'Joint Press Conference'.

${ }^{127}$ Bergman Rosamond, 'The digital politics of celebrity activism'.

${ }^{128}$ Gray and Franck, 'Refugees as/at risk'.
} 


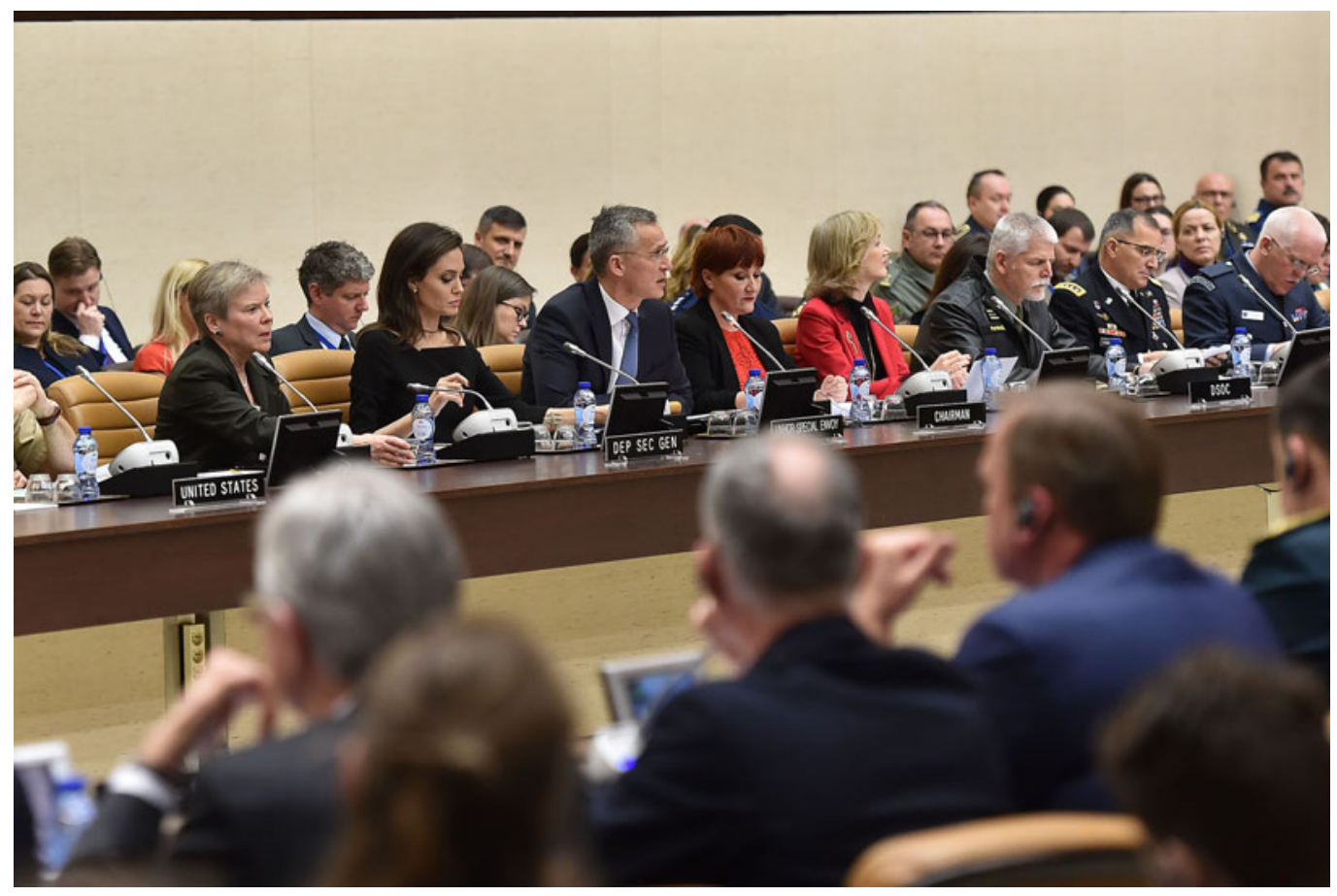

Figure 3. Angelina Jolie sits next to Deputy Secretary General Rose Gottemoeller and Secretary General Jens Stoltenberg at the specially convened joint meeting of the North Atlantic Council/Military Committee.

Source: NATO, 'Visit to NATO'. Image used under NATO's 'fair use' policy: \{https://www.nato.int/cps/en/natohq/68162.htm\}.

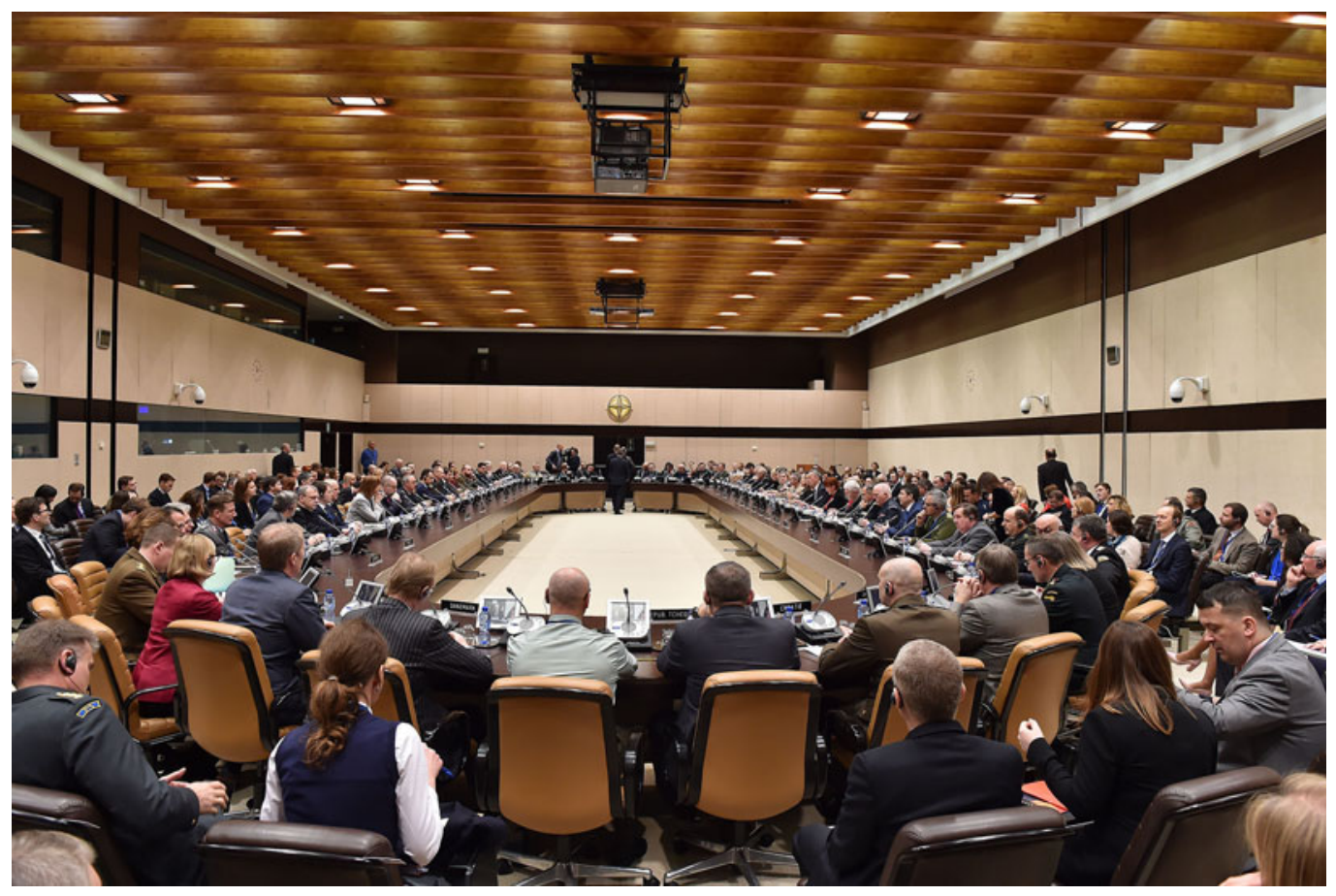

Figure 4. Angelina Jolie addresses the joint meeting of the North Atlantic Council/Military Committee. Source: NATO, 'Visit to NATO'. Image used under NATO's 'fair use' policy: $\{$ https://www.nato.int/cps/en/natohq/68162.htm\}. 


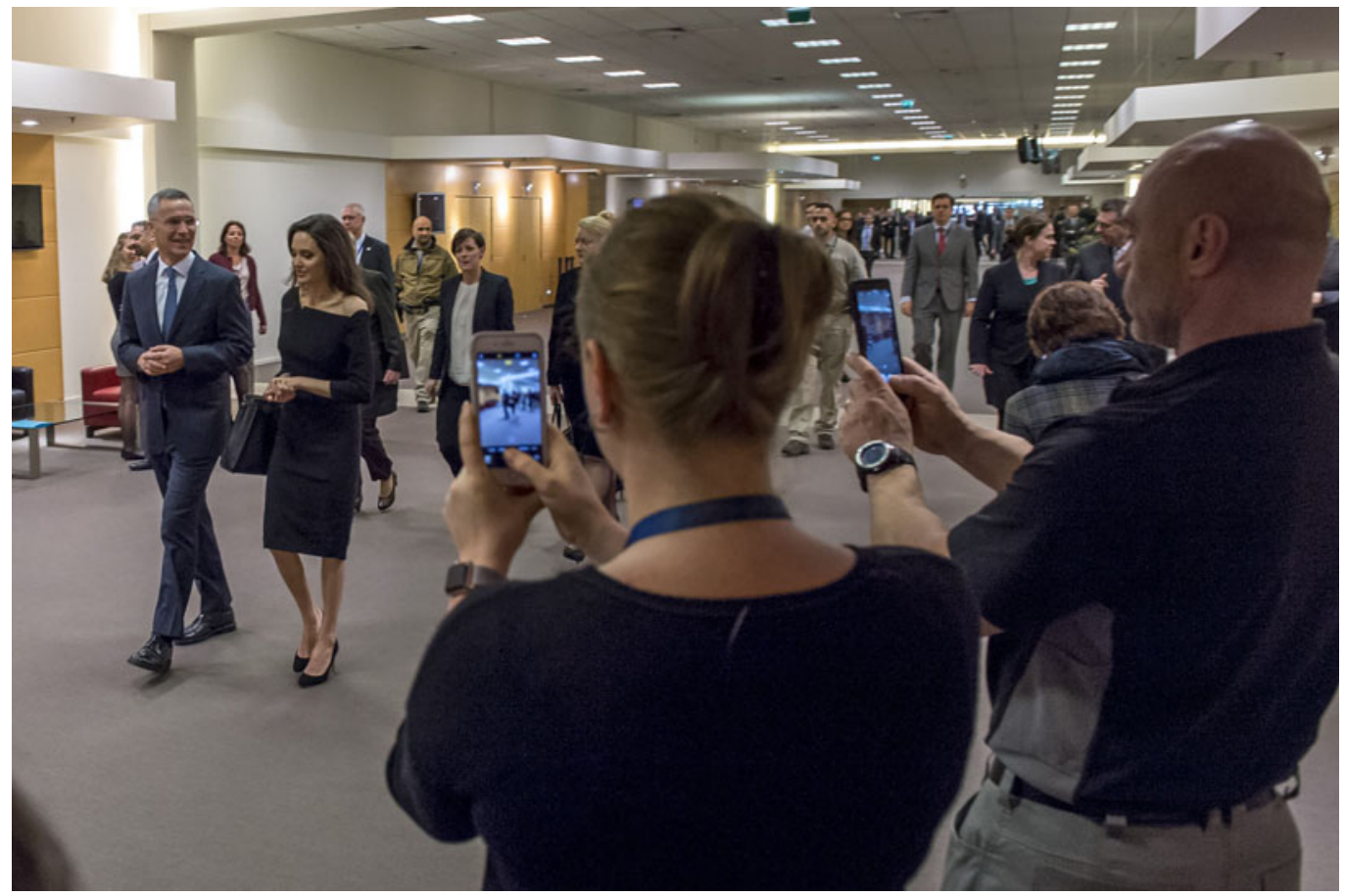

Figure 5. NATO staff snap pictures on their phones as Angelina Jolie is accompanied on her tour of NATO HQ by Secretary General Jens Stoltenberg. Source: NATO, 'Visit to NATO'. Image used under NATO's 'fair use' policy: \{https://www.nato.int/ cps/en/natohq/68162.htm\}.

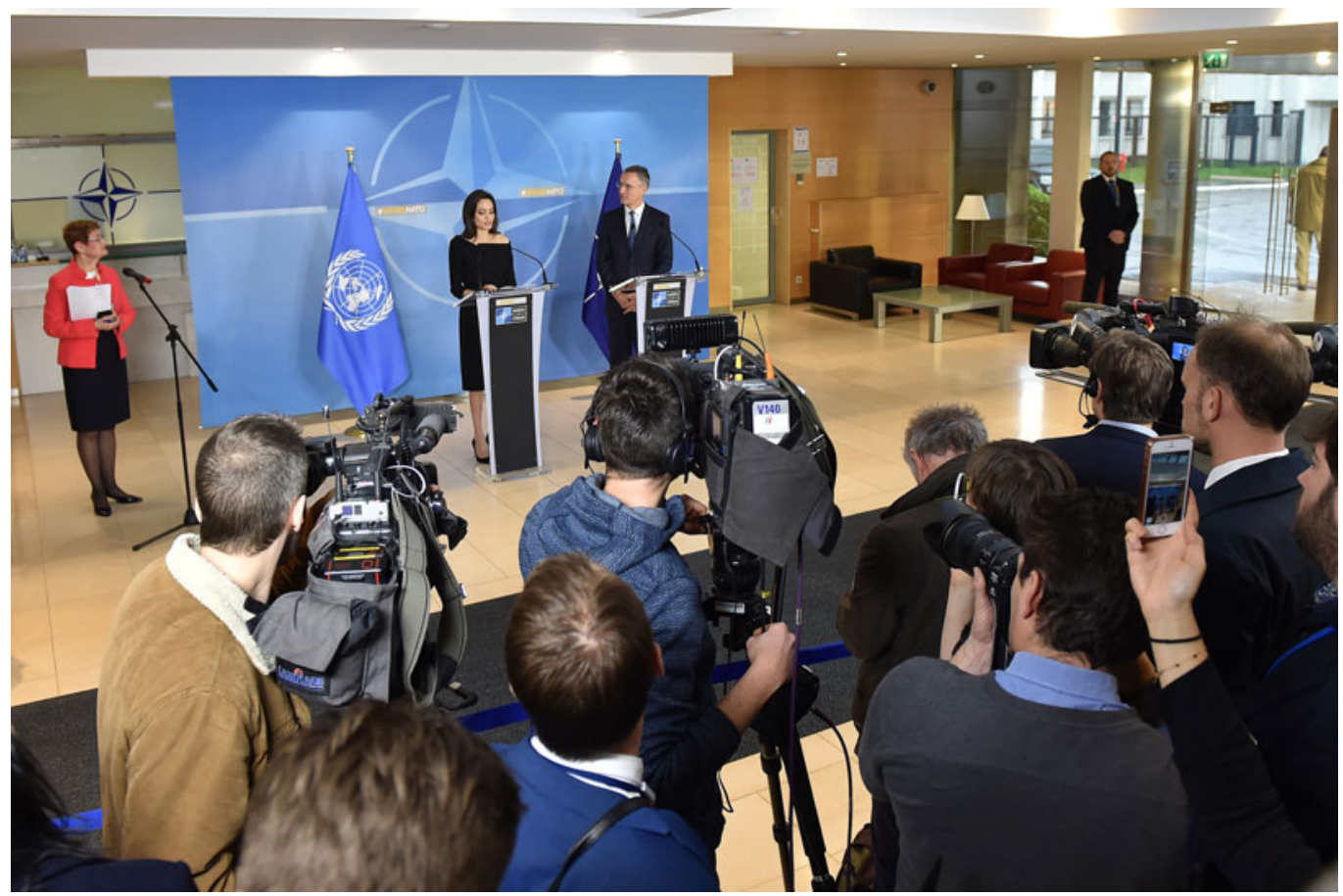

Figure 6. Angelina Jolie and Secretary General Jens Stoltenberg address the press conference. Source: NATO, 'Visit to NATO'. Image used under NATO's 'fair use' policy: $\{$ https://www.nato.int/cps/en/natohq/68162.htm\}. 
reception in the media and among wider audiences, including what questions the press reported on. There were opportunities in the press conference for more critical engagement with NATO's CRSGBV work, for example, one reporter from the Wall Street Journal asked: 'Is NATO and the Resolute Support Mission [in Afghanistan] doing enough to protect children from sexual exploitation by NATO trained forces?', a highly sensitive issue for NATO members. ${ }^{129}$ In their replies, Stoltenberg stated that NATO has 'done a lot', without being specific on what that was and Jolie responded that 'Afghanistan is a country I have been to a few times, very dear to my heart' and 'there is a lot more work to be done'. Neither of these questions, nor the beleaguered responses, were picked up on in any of the media coverage, and thus this more critical account of NATO did not permeate popular culture and were therefore missing from the reception of NATO's selfnarrative. As we go onto discuss, such coverage focused on Jolie's looks, motherhood, and jet-set lifestyle. This corresponds to previous findings on the reception of Jolie's activism, often stripping out the politics to focus on the aesthetics. ${ }^{130}$ In this case, contributing to shaping a self-narrative of NATO as an actor for gender justice and further contributing to a wider depoliticised CRSGBV issue narrative. Next, we provide an analysis of the issues arising from NATO's efforts to transform its self-narrative to become a leading actor in the field of CRSGBV, focusing on its attempts to position itself as a 'military leader' on tackling CRSGBV and constitutively introducing 'awareness raising' of NATO's role in addressing the issue as a tool in and of itself to address CSRGBV thus shaping the wider issue narrative.

\section{Military leadership on CSRGBV}

Our analysis of the visit, press conference and resulting coverage find an attempt to constitute NATO as a military leader in responding to CRSGBV. The quest for leadership prevails in contemporary efforts to tell the story of NATO as a 'gender-just' military alliance. However, the articulation of that specific theme rests on an assumption that sexual violence in conflict is solely a 'tactic of war' and neglects the potential of NATO troops to be perpetrators, rather than just 'reporters' of sexual violence. In the Guardian op-ed on NATO's response to CRSGBV, jointly authored by Stoltenberg and Jolie, NATO is constituted as a defender of democratic values and CRSGV as a 'tactic of war'. In their words:

We believe that Nato [sic] has the responsibility and opportunity to be a leading protector of women's rights.

In particular, we believe Nato can become the global military leader in how to prevent and respond to sexual violence in conflict, drawing on the strengths and capabilities of its member states and working with its many partner countries. ${ }^{131}$

The desire to become a global leader, moreover, is linked to NATO's willingness to take on board a responsibility for the eradication of CRSGV and therefore contribute to shaping the wider issue narrative. The bilateral partnership with Jolie and her previous CRSGV advocacy adds legitimacy to that quest for leadership. It also echoes NATO's wider engagement with WPS, which has been carried out through partnership with external actors. ${ }^{132}$ For example, Jolie's visit was later claimed as evidence by the Secretary General that NATO was 'doing Women, Peace and Security'. ${ }^{133}$ Jolie's role is both to bring CRSGV-related issues to NATO's attention, but also to confer legitimacy on NATO's self-narrative as a world leader. She does so by highlighting the

\footnotetext{
${ }^{129}$ Hebert, 'Analyzing UN and NATO responses'.

${ }^{130}$ See also Bergman Rosamond, 'The digital politics of celebrity activism'.

${ }^{131}$ Jens Stoltenberg and Angelina Jolie, 'Why Nato must defend women's rights', The Guardian (2017), available at: \{https://www.theguardian.com/commentisfree/2017/dec/10/why-nato-must-defend-womens-rights\} accessed 11 April 2018.

${ }^{132}$ Wright, 'Telling NATO's story of Afghanistan'.

${ }^{133}$ Wright, Hurley, and Ignacio Ruiz, NATO, Gender and the Military, p. 14.
} 
need 'to make NATO the global leader, [the] military leader in this area'134 and her visit and partnership with NATO adds visibility to that leadership role.

This articulation of NATO's self-narrative was picked up in traditional and social media coverage with People quoting the Secretary General Jens Stoltenberg's assertion that 'NATO has the responsibility to be a leading protector of women's rights.' Jolie and Stoltenberg gave a long press conference, so it matters what is reported on. The focus on these particular lines is significant because they narrate NATO within gender binaries, pertaining to the alliance being a 'saviour'/good and those who commit CRSGBV as inherently evil, again reinforcing the masculinist and racialised protection logic evident in NATO's wider engagement with WPS, ${ }^{135}$ and reinforcing a simplified issue narrative concerning CRSGBV belying its reality. ${ }^{136}$

The projection and reception of Jolie was highly visual. While the focus of the co-authored Guardian op-ed is NATO, the article features just one photograph, a close-up portrait of Jolie with minimal makeup and a sombre look on her face. ${ }^{137}$ The visual representation of Jolie, a leader in her own right and a supporter of NATO can add rigour to its search for CRSGBV leadership. The digital coverage in PopSugar focuses on Jolie's ability to enable NATO in its efforts to 'raise awareness' of the issue of sexual violence. ${ }^{138}$ In PopSugar, Jolie's attire is visually projected, drawing attention to her beauty in 'a black off-the-shoulder dress', although the photograph included is a press shot of Jolie and Stoltenberg shaking hands during the press conference. ${ }^{139}$ The focus on Jolie's appearance and beauty, rather than the substance of the visit, is thus reinforced by the use of photographs of Jolie's NATO visit, all of which were taken during the press conference. Her beauty was also front and centre of the Daily Mail Online's coverage: 'The Oscar-winning actress, 42, wore a caped black dress and matching heels for her meeting with NATO secretary general Jens Stoltenberg. ${ }^{140}$ The visual element of this coverage focuses on Jolie picking up her handbag following the press conference with 'Jens' [Stoltenberg] seemingly helping her. This is reflective of the gendered and often shallow projection of celebrity humanitarianism, being attentive to the beauty, dignity, and dress sense of the celebrity in question, rather than the message they seek to deliver. ${ }^{141}$ The visual projection of Jolie is a mechanism to draw readers in, and, represent her as an agent of change adding legitimacy and knowledge to NATO's self-narrative as a CRSGBV leader, and ensuring its reception and contributing to it acceptance by the audience. For example, in an interview in Elle magazine, conducted by John Kerry, Jolie's work with NATO is constituted as a training and protection strategy, and as a way of 'getting more women in the military'. ${ }^{142}$

In a similar vein, The Daily Mail Online frames Jolie's visit to NATO as 'the latest stop on Angelina's tour of Europe', prior to meeting France's First Lady Brigitte Macron to 'discuss her recent visit to Jordan and urge members of the UN Security Council to resolve the conflict in Syria' and before attending 'a beauty launch at the Guerlain headquarters'. The Daily Mail Online only touches briefly on the purpose of Jolie's visit to NATO by citing the Guardian

\footnotetext{
${ }^{134}$ NATO, 'Joint Press Conference'.

${ }^{135}$ Hurley, 'Watermelons and weddings'; Wright, 'Telling NATO's story of Afghanistan'; Wright, Hurley, and Ignacio Ruiz, NATO, Gender and the Military.

${ }^{136}$ Gray and Franck, 'Refugees as/at risk'.

${ }^{137}$ Stoltenberg and Jolie, 'Why Nato must defend women's rights'.

${ }^{138}$ Monica Sisavat, 'Angelina Jolie visits NATO to fight for women's rights, and world leaders should pay attention', PopSugar (2018), available at: \{https://www.popsugar.co.uk/celebrity/Angelina-Jolie-NATO-Headquarters-Belgium-January2018-44544511\} accessed 28 May 2019.

${ }^{139}$ Ibid.

${ }^{140}$ Eve Buckland, 'Angelina Jolie visits NATO headquarters in Belgium to discuss prevention of sexual violence against women in warzones ... as her tour of, Daily Mail Online (2018), available at: \{https://www.dailymail.co.uk/tvshowbiz/article-5334467/Angelina-Jolie-visits-NATO-headquarters-Brussels.html\} accessed 24 February 2020.

${ }^{141}$ Bergman Rosamond, 'The digital politics of celebrity activism'.

${ }^{142}$ John Kerry, 'What Angelina Jolie is fighting for now', Elle (2018), available at: $\{$ https://www.elle.com/culture/celebrities/ a16642591/angelina-jolie-march-cover-2018/\} accessed 11 April 2018.
} 
op-ed that 'Angelina and Jens united for' to enquire 'how the NATO alliance could be a role model and "leading protector" of women's rights, and ending gender-based violence'. ${ }^{143}$ The attention and focus on Jolie, rather than NATO, constitutes the alliance as 'everyday and unremarkable', while the association with celebrity makes it 'morally good', contributing to what Merje Kuus ${ }^{144}$ describes as 'banal militarism: an unremarkable assumption that the military apparatus is ethically grounded and capable for achieving peace'. This form of militarism is compounded with the use of new media technology with social media and a focus on visuality enabling 'traditional and new actors involved in processes of militarization to communicate their messages in novel ways, in real time, and to potentially larger audiences at a lower cost than was previously possible'. ${ }^{145}$

Jolie's visit, moreover, creates awareness of CRSGBV matters, while reassuring NATO member states and beyond that the alliance is taking action by highlighting the significance of the agenda. Jolie's celebrity status, as well as her official role as a UN Special Envoy, adds force to NATO's quest for global CRSGBV leadership. ${ }^{146}$ As the Metro.Style coverages notes, 'the fulltime mother isn't just an Oscar-winning actress and director, she's also been the Special Envoy for the United Nations High Commissioner for Refugees'. ${ }^{147}$ We suggest here that the visual storytelling that surrounds Jolie's visit as a high-ranking UN diplomat adds visibility and credibility to her actions, while being key to raising positive associations for NATO with a cause, and, among audiences that the alliance does not usually reach. Moreover, it can be linked to NATO's position that 'awareness raising' in itself constitutes action on CRSGBV, which we discuss next.

\section{Awareness raising}

At the joint press conference by 'NATO Secretary General Jens Stoltenberg and UN Special Envoy Angelina Jolie' during her visit to NATO HQ in Brussels, it was repeatedly noted that raising awareness about CRSGBV is a means to trigger action. ${ }^{148}$ Stoltenberg stated that 'words are important, awareness is important because that's the first step towards action'. ${ }^{149}$ Awareness has therefore become part of NATO's WPS work and response to CRSGBV and is linked with its selfnarrative as a military leader.

Jolie's association with NATO sparked a significant increase in awareness of the alliance, with many media and social platforms across the globe extensively covering her visit to Brussels, including, as noted above, celebrity focused publications that NATO would not usually feature in. What is more, many of the readers of such texts are likely to be women, a stark contrast to the usual demographic engaging with NATO. ${ }^{150}$ The hashtag '\#WeAreNATO' was used extensively by different NATO Twitter accounts, both individual and institutional. Jolie's visit was discursively constituted as part of NATO's public diplomacy efforts, with one Twitter user commenting:

Like every day at \#NATO, it's all about security - but today along w @UN Special Envoy Angelina Jolie, it's about doing more for \#WomenPeaceSecurity. Delighted to be part of the beating heart of NATO's public diplomacy \#WeAreNATO.

\footnotetext{
${ }^{143}$ Buckland, 'Angelina Jolie visits NATO'.

${ }^{144}$ Kuus, "Love, peace and Nato"', p. 369.

${ }^{145}$ Jackson et al., 'Forum: Militarization 2.0'.

${ }^{146}$ Bergman Rosamond, 'Global motherhood and celebrity politics'.

${ }^{147}$ Sara de los Reyes, 'Angelina Jolie aces her multi-hyphenate life: Here's how she does it', Metro.Style (2018), available at: \{https://metro.style/people/celebrities/angelina-jolie-aces-her-multihyphenate-life/8167\} accessed 24 February 2020.

${ }^{148}$ NATO, 'Joint Press Conference'.

${ }^{149}$ Ibid.

${ }^{150}$ Author's personal correspondence with a NATO official.
} 
This reinforces Katharine A. M. Wright's ${ }^{151}$ findings that WPS has served as an effective public diplomacy tool for NATO. Certainly, Jolie's visit and subsequent press coverage seems to bear out the utility of messaging on WPS for engaging with 'new' audiences and contributing to the wider reception of this strategic narrative. However, it is not evident how raising awareness among these audiences can address the issue of sexual violence in conflict or challenge the masculinist protection and militaristic logic that surround it. ${ }^{152}$

When we turn to how the message on CRSGBV projected by NATO and Jolie was received, we see that nuance is lost, again undermining the efficacy of awareness raising as action on CRSGBV, but contributing to NATO's self-narrative that projects its role as a military leader for gender justice. For example, Metro.Style perpetuates an essentialised view of women in conflict - lacking agency and power - a position that Jolie herself ascribed to the victims of sexual violence at the press conference:

The leading lady expressed her concern about women undergoing emotional, physical, and psychological distress during these trying times, and how adding sexual violence to the formula would undisputedly leave them scarred and pained, for life. ${ }^{153}$

As has been noted above, a critical feminist reading of Jolie's diplomacy and humanitarianism finds that digital and traditional media tends to constitute her activism within the language of maternal care. ${ }^{154}$ Indeed, Daily Mail Online coverage of Jolie's visit to NATO focused on her global motherhood: 'The mother of six flashed a smile as she shook hands with Jens during the photo call before she was treated to a tour of the military base', with her advocacy work presented as a nice addition to her lifestyle but the issue itself, CRSGV, left interrogated. ${ }^{155}$

Awareness raising, leadership, and training are intertextually linked across texts, ${ }^{156}$ with Jolie stating that 'we are going to focus on training, reporting, monitoring and awareness as a way of ending impunity'. ${ }^{157}$ NATO's military leadership on this issue is presented as raising awareness among its partners of their need to do more to address CRSBV together with the alliance, in terms of supporting increasing women in the military and offering training of military staff. NATO's awareness raising helps to sustain its self-narrative as a competent actor working to eradicate CRSGV, assigning incompetence and malfunctioning to the armed forces of others. Thus, its self-narrative is imbued with innocence, locating the alliance in juxtaposition to other less competent states. This is evident in the Guardian op-ed, which emphasises NATO's leadership role in 'helping to raise the standards of other militaries', a message that is reinforced in Stoltenberg's comments at the press conference: 'NATO is training partner militaries around the world. We will look to strengthening existing training on combatting sexual violence. ${ }^{158}$ This emphasis is reflective of NATO's wider engagement with the WPS agenda to-date, which has prioritised relationships with partners, leading to an external facing focus to its WPS work. ${ }^{159}$ Jolie's visit when read in this wider context also presents her as a partner to NATO, bringing

\footnotetext{
${ }^{151}$ Wright, 'Telling NATO's story of Afghanistan'.

${ }^{152}$ The narrow focus NATO and Jolie take in their understanding of what sexual violence in conflict is, how it emerges and what the response should be, could, nevertheless detract from calls to recontextualise sexual- and gender-based violence in conflict against wider patterns resulting from imbedded gendered inequalities in societies. See also Meger, 'The fetishization of sexual violence'.

${ }^{153}$ Reyes, 'Angelina Jolie aces her multi-hyphenate life'.

${ }^{154}$ Bergman Rosamond, 'The digital politics of celebrity activism'; Bergman Rosamond, 'Global motherhood and celebrity politics'; Richey and Brockington, 'Celebrity humanitarianism'; Mostafanezhad, 'Angelina Jolie and the everyday geopolitics'.

${ }^{155}$ Buckland, 'Angelina Jolie visits NATO'.

${ }^{156}$ Stoltenberg and Jolie, 'Why Nato must defend women's rights'; NATO, 'Joint Press Conference'; Kerry, 'What Angelina Jolie is fighting for now'.

${ }^{157}$ NATO, 'Joint Press Conference'.

${ }^{158}$ Ibid.

${ }^{159}$ Wright, 'NATO’s adoption of UNSCR 1325'; Wright, 'Telling NATO’s story of Afghanistan', p. 118.
} 
her expertise, celebrity, and UN status to NATO's cause through creating awareness, with NATO in turn supporting her in her aims to address CRSGBV by bringing its political-military leadership to bear to bring partners 'into line'.

Moreover, NATO's leadership through awareness raising invokes increasing women in the armed forces as a solution to impunity, and as such, further shapes the issue narrative. For example, a direct link was made by Jolie between 'NATO's potential role in helping to create greater global accountability and deterrence for crimes against women in conflict zones' and a need to 'increase the representation of women in militaries', which she raised during her visit to NATO. ${ }^{160}$ This builds on the Guardian op-ed in which Jolie states that 'Nato's senior military leaders, have a vital role to play in being positive role models, and promoting the role of women in the military. ${ }^{161}$ This also shows that NATO's quest for leadership is constitutively linked to its emphasis on women's representation in the military. However, this largely ignores that this co-constitutive relationship is gendered, assigning specific qualities to women soldiers. Thus, both NATO and Jolie employ gender binaries by assuming that adding women to the military would solve the problem of sexual violence in conflict. NATO has previously articulated this idea as part of the 'added value' NATO ascribes to the recruitment of more women into its armed forces. ${ }^{162}$ However, the employment of such stereotypical notions of women soldiers' distinct ability to eradicate CRSGBV and end impunity disregard the structural and gendered roots of such violence. Yet, Jolie through her partnership with NATO, brings her global celebrity credentials to bear in shaping the issue narrative on CRSGBV and therefore the shape of subsequent policy discussions. ${ }^{163}$ She also contributes to NATO's self-narrative by presenting the alliance as a 'role model', belying the reality that women remain significantly underrepresented in NATO's armed forces. ${ }^{164}$ Finally, there are few signs of Jolie critically reflecting on the militarising logic and the 'banal militarism" ${ }^{\text {'165 }}$ that underpin such thinking and NATO's CRSGBV leadership more broadly.

\section{Conclusions}

This article has examined the significance of Angelina Jolie's visit to NATO in January 2018 for the alliance, both in terms of its approach to the wider WPS agenda and its projection, but also the reception of its self-narrative through engaging with celebrity and visuals to shape the distinctive issue narrative of CRSGBV. Our analysis shows that in an increasingly connected digital world, visuals and texts have become inseparable and co-constitutive of each other, with a visit by a celebrity creating awareness of NATO's self-narrative as a military leader in addressing CRSGBV. Likewise, Jolie's reception by NATO adds to her celebrity diplomat/humanitarian credentials and brand by constituting her visually and textually as a bilateral partner of the alliance. Our study then contributes to emergent research on the role of individuals and celebrity in advancing the WPS agenda. ${ }^{166}$ It also raises questions regarding celebrities' engagements with security and defence actors such as NATO on CRSGBV matters, in particular since the alliance, despite its commitment to gender-justice, also contains discourses that are not necessarily in line with critical feminist quests for demilitarisation and peace. As we have argued, Jolie's visit to NATO opened the alliance to public scrutiny, however, its transmission in popular culture symbolised a form of militarism that was orchestrated through visual representations, and, as such only marginally disrupted the militarised logic present in NATO's wider WPS engagement.

\footnotetext{
${ }^{160}$ NATO, 'Joint Press Conference'.

${ }^{161}$ Ibid.

${ }^{162}$ Wright, Hurley, and Ignacio Ruiz, NATO, Gender and the Military, p. 111.

${ }^{163}$ Miskimmon, O'Loughlin, and Roselle, Strategic Narratives, p. 7.

${ }^{164}$ Wright, Hurley, and Ignacio Ruiz, NATO, Gender and the Military.

${ }^{165}$ Kuus, "Love, peace and Nato"'.

${ }^{166}$ Bergman Rosamond, 'The digital politics of celebrity activism'; Hudson and Budabin, 'When advocacy securitizes'.
} 
Our article also provides an important contribution to work on the little studied role of celebrity in the security and defence sector and the value of foregrounding celebrity and popular culture from a gender perspective in interrogating the reception of strategic narratives. We have demonstrated that for actors such as NATO, the 'right' celebrity can extend their reach beyond the audiences that it would usually engage with. Moreover, superficial coverage of the visit in the celebrity press served to associate NATO with the 'goodness' of Jolie's humanitarian credentials, even if NATO itself was not always the focus of that coverage. Angelina Jolie was portrayed as a bilateral partner of NATO, rather than working for the alliance. Despite opening up NATO to further scrutiny pertaining to its involvement with the WPS agenda, the visit and awareness raising did not challenge the 'banal militarism' ${ }^{\text {'67 }}$ underpinning NATO, but rather marked a temporal shift to its grounding in celebrity and popular culture. While Jolie's celebrity status evoked interest among global audiences and as such raised the awareness of NATO as a promoter of WPS matters, the ethical and gender-based substance of her visit and nuance of subsequent interventions were lost in the extensive coverage of her aesthetic appeal. This points to the significance of critically studying the role of individual celebrities in constituting security discourses and practices in global gender politics. ${ }^{168}$

Jolie's visit marked a reaffirmation of NATO's adoption of the WPS agenda as a core theme of its global brand and self-narrative, beautifying NATO through the projection of celebrity and with a strong emphasis on visual projections of the Jolie-NATO partnership. The visit and its wider reception emphasised NATO's role as a 'military leader' in addressing CRSGBV through 'awareness raising', in particular the training of partners and increasing women in (partner states') militaries, avoiding implicating NATO or its member states in an issue that has proved sensitive for the alliance. ${ }^{169}$ That narration, however, does not critically engage with the militarism underpinning NATO's thinking on CRSGBV. Yet, as our analysis shows, we should be cautious before we claim that 'awareness raising' constitutes actual implementation of the WPS agenda. Nor should we assume that that it is sufficient in addressing the issue of sexual violence in conflict. The issue narrative surrounding NATO's engagements with CRSGBV, moreover, forwent broader structural understandings of its grounding within the domestic patriarchy, and the essentialised and much problematised assumption that adding women to the military can in itself address the issue of CRSBV. Our analysis and findings therefore reinforce the importance of interrogating strategic narratives and the stories of WPS told by NATO to understand how they have been institutionalised, ${ }^{170}$ adding to this the importance of including their reception through stories told, and visuals projected, in wider media coverage and popular culture. We also identify the need to interrogate the co-constitutive effects of the projection and reception of identity and issue narratives, something which future work could further interrogate.

Acknowledgements. Previous versions of this article have been presented at the 2019 British International Studies Association (BISA) annual conference, the 2019 European Conference on Politics and Gender (ECPG), the Gender Research Centre at Bristol University, and Lund University. The authors would like to thank the discussants and audiences for their valuable comments, along with the anonymous reviewers. Thank you to the Marianne och Marcus Wallenberg Stiftelse/Foundation for their support in the writing of this article.

Katharine A. M. Wright is Senior Lecturer in International Politics at Newcastle University (UK). Her research explores the intersection of gender and security in institutional settings, including the engagement of NATO and the EU with the Women, Peace and Security agenda, and has been published in a range of leading journals. She is co-author of NATO, Gender and the Military: Women Organising from Within (Routledge, 2019) which received an honourable mention in the 2019 BISA Susan Strange Book Prize. At Newcastle she co-convenes the Military, War and Security Research Group. Author's Twitter profile: @KAMWright

\footnotetext{
${ }^{167}$ Ibid.

${ }^{168}$ Bergman Rosamond, 'Global motherhood and celebrity politics'.

${ }^{169}$ Hebert, 'Analyzing UN and NATO responses'.

${ }^{170}$ Wright, 'Telling NATO's story of Afghanistan'; Hurley, 'Watermelons and weddings'.
} 
Annika Bergman Rosamond is Associate Professor at the Department of Political Science, Lund University. She is the author of Women Peace and Security - and Denmark (2014); Protection Beyond Borders: Gender Cosmopolitanism and Co-constitutive Obligation (Global Society, 2013); Swedish Feminist Foreign Policy and Gender Cosmopolitanism (Foreign Policy Analysis, 2020); Cosmopolitan Militaries and Dialogic Peacekeeping: Danish and Swedish Women soldiers in Afghanistan (with A. Kronsell, International Feminist Journal of Politics, 2018); and Theorising Feminist Foreign Policy (with Karin Aggestam and Annica Kronsell, International Relations, 2019). At Lund she convenes the Gender and Politics research group. Author's Twitter profile: @BergmanRosamond

Cite this article: Wright, K. A. M., Bergman Rosamond, A. 2021. NATO's strategic narratives: Angelina Jolie and the alliance's celebrity and visual turn. Review of International Studies 47, 443-466. https://doi.org/10.1017/S0260210521000188 